\title{
Predicting trust in online advertising with an SEM-artificial neural network approach
}

\author{
Lai-Ying Leonga,, ${ }^{\mathrm{a},}$ Teck-Soon Hew ${ }^{\mathrm{b}}$, Keng-Boon Ooi ${ }^{\mathrm{c}, \mathrm{d}}$, Yogesh K. Dwivedi ${ }^{\mathrm{e}}$

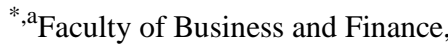 \\ Universiti Tunku Abdul Rahman, \\ Jalan Universiti, Bandar Barat, 31900 Kampar, Perak, Malaysia \\ Email: lyennlly@gmail.com \\ ${ }^{b}$ Faculty of Business and Accountancy, \\ University of Malaya, 50603 Kuala Lumpur, Malaysia \\ Email: hewtecksoon@gmail.com \\ ${ }^{c}$ Faculty of Business and Information Science, \\ UCSI University, No. 1 Jalan Menara Gading, \\ UCSI Heights, 56000 Cheras, Kuala Lumpur, W. P. Kuala Lumpur, Malaysia \\ Email: ooikengboon@gmail.com \\ ${ }^{\mathrm{d}}$ College of Management, \\ Chang Jung Christian University \\ 711, Taiwan, Tainan City, Guiren District \\ Email: ooikengboon@gmail.com \\ eEmerging Markets Research Centre (EMaRC), \\ School of Management, \\ Swansea University Bay Campus, \\ Fabian Way, Swansea SA1 8EN, United Kingdom \\ Corresponding author \\ Email: ykdwivedi@gmail.com
}

\section{*Corresponding author:}

Dr. Leong Lai Ying

Assistant Professor

Department of Commerce \& Accountancy

Faculty of Business and Finance

Universiti Tunku Abdul Rahman Kampar Campus

Jalan Universiti, Bandar Barat, 31900 Kampar

Perak Darul Ridzuan, Malaysia

Tel No: (605) 4688888 Ext. 4325

Fax: +605-4667407

\begin{abstract}
Trust has an imperative role in online advertising because the effectiveness of the adverts will be greatly affected when consumers distrust online adverts. Currently, the level of consumers' trust in online advertising remains low. The current study will assess the drivers of trust by integrating the Trust Building Model and the ADTRUST scale. Unlike present literature that utilized linear models, a Structural Equation ModellingArtificial Neural Network (SEM-ANN) approach was used. This is because consumers' trust-building is a complex process and linear models will over-simplify the complexity in the decision-making processes. Thus, the outcomes from linear models are inadequate and inaccurate to explicate the mechanism of trust creation in online advertising. Data were gathered from 500 online consumers using a mall intercept technique. The outcomes from the sensitivity analysis show that reliability is the most imperative antecedent of trust followed by website quality, willingness to rely on, reputation, and hours spent. The model predicts $76.14 \%$ trust in online advertising. The theoretical implication is the integration of the ADTRUST scale with the Trust Building Model. The methodological implication is the use of the SEM-ANN approach that captured both linearnonlinear and compensatory-non-compensatory associations. The findings provide some useful practical implications for online advertisers, service providers, and retailers. The study has contributed useful theoretical and practical implications to the online marketing literature.
\end{abstract}

Declaration of interest: none 


\title{
Predicting trust in online advertising with an SEM- artificial neural network approach
}

\begin{abstract}
Trust has an imperative role in online advertising because the effectiveness of the adverts will be greatly affected when consumers distrust online adverts. Currently, the level of consumers' trust in online advertising remains low. The current study will assess the drivers of trust by integrating the Trust Building Model and the ADTRUST scale. Unlike present literature that utilized linear models, a Structural Equation Modelling-Artificial Neural Network (SEM-ANN) approach was used. This is because consumers' trust-building is a complex process and linear models will over-simplify the complexity in the decision-making processes. Thus, the outcomes from linear models are inadequate and inaccurate to explicate the mechanism of trust creation in online advertising. Data were gathered from 500 online consumers using a mall intercept technique. The outcomes from the sensitivity analysis show that reliability is the most imperative antecedent of trust followed by website quality, willingness to rely on, reputation, and hours spent. The model predicts $76.14 \%$ trust in online advertising. The theoretical implication is the integration of the ADTRUST scale with the Trust Building Model. The methodological implication is the use of the SEM-ANN approach that captured both linear-nonlinear and compensatory-non-compensatory associations. The findings provide some useful practical implications for online advertisers, service providers, and retailers. The study has contributed useful theoretical and practical implications to the online marketing literature.
\end{abstract}

Keywords: Consumer trust, Online advertising, Trust building model, ADTRUST, Artificial neural network 


\section{Introduction}

Online advertising enables vendors to gain higher content evaluations, greater recall, and more sales (Aguirre, Mahr, Grewal, de Ruyter, \& Wetzels, 2015). Starting from the first online advertising banner, online advertising has grown rapidly and attributed a large percentage of the advertising expenditure (Liu-Thompkins, 2019). Across various product categories, vendors use to allocate a large amount of investment in advertising (Tuli, Mukherjee, \& Dekimpe, 2012; Zenetti \& Klapper, 2016). For instance, USD 2.9 billion is spent annually in advertising by Walmart (Blut, Teller, \& Floh, 2018). In 2015, almost USD 170 billion was consumed worldwide on online advertising and it is estimated that in 2021 the figure will reach 330 billion USD (Statista, 2019b). Based on the analysis by IndustryARC (2019), the online advertising market had grown to USD 240 billion in 2018 and is anticipated to expand at an astounding compound annual growth rate of $37 \%$ to $40 \%$ from 2019 to 2025. In addition, online advertising in the U.S. is expected to reach USD 93.5 billion by 2020 from USD 80 billion in 2016 (Statista, 2019b).

Even though online advertising has huge market potential and can generate enormous revenue, however, the level of consumer trust towards online advertising remains low in comparison to other forms of advertising. Figure 1 (Statista, 2019a) shows that consumer's trust towards online video ads, search advertising, social media advertising, online banner ads, display ads, and text ads on mobile devices occupy the bottom portion on the list. Therefore, knowledge of the determinants of consumers' trust in online advertising is vital for profit-sustainability as well as uplifting the effectiveness of online advertising. Without a good knowledge of how consumers trust may be established in online advertising, it would be very difficult to attain a high level of advertising efficiency and this would mean that the money spent on online advertising would not contribute equivalent return of investment to the marketers, vendors, and retailers.

$<$ Figure 1 about here>

Online advertising is referred to as "deliberate messages placed on third-party web sites including search engines and directories available through Internet access" (Ha, 2008, p. 3). Generally, the online advertising literature may be classified into six main research themes namely advertising 
effectiveness, the role of context in online advertising, advertising mechanism, creative elements in online advertising, search advertising, and online personalization (Liu-Thompkins, 2019). Unfortunately, consumer trust in online advertising has been overlooked in the extant literature. Therefore, there is an immediate necessity to address this void in order not to miss the state-of-the-art technological bandwagon.

There are several motivations for this study; first, we address the void in studies on consumer trust in online advertising that currently exists. Based on our understanding, currently, there has been hardly any research on what causes the creation of consumers' trust in online advertising. With the extant study, we can provide the necessary theoretical foundation that can contribute to the extant literature. Second, we extended the trust-building model (TBM) by integrating the ADTRUST scale. TBM has been used in various researches to examine initial trust towards marketers, vendors, and retailers but not on consumers' initial trust towards online advertising. It is important that once consumers come across an online advertisement for the first time, they can build up their trust towards the online ads. Third, we also included demographic information of gender, education, age, and hours spent as the control variables to improve the research model as well as its predictive power. Finally, unlike most of the retailing and marketing studies that examine linear relationships using a conventional statistical approach including multiple linear regression, structural equation modeling, logistic regression, and etc.furthermore we engaged a two-staged SEM-ANN analysis. This is because consumer decision on whether to trust an online advertisement or not, cannot be fully explained using linear models as it is a complex process. Thus, by using a combination of the linearnonlinear SEM-ANN model, we are able to conduct hypothesis testing for linear relationships as well as identifying the ranks of the importance of the input neurons according to the neural network sensitivity analysis that can capture the non-compensatory and nonlinear relationships (Leong, Hew, Ooi, \& Chong, 2020). In a linear compensatory model, a decline in a particular factor may be recompensed by an increment in other factors (Leong, Hew, Ooi, \& Wei, 2019). Nevertheless, most of the time, this is not true because of a decline in reliability, for example, may not be recovered by promoting the usefulness level. Though Artificial Neural Network (ANN) has superb predictive power, however, it is not suitable for hypothesis testing as it does not require theoretical support 
(Leong, Hew, Ooi, \& Tan, 2019). Hence, by using a hybrid SEM-ANN which can cover both hypotheses testing of linear relationships in the compensatory model while capturing the nonlinear non-compensatory relationships in the ANN model, we have offered a new approach in examining consumers' trust towards online advertising.

The paper uses the following layout. We commence with an introduction and then expound the extant literature. After that, the theoretical underpinning, theoretical framework, and hypotheses formulation were presented. Next, the research method and statistical analyses are reported and then a discussion, as well as the theoretical, and managerial implications, were presented (Leong et al., 2020). We end the paper with the conclusion, limitation, and upcoming research direction.

\section{Literature Review}

A primary factor that attracts and retains consumers and influences their behaviors is trust (Davis, Sajtos, \& Chaudhri, 2015). A high degree of trust may lead to a surge in intention to purchase and product evaluations (Orth, Bouzdine-Chameeva, \& Brand, 2013). Trust is particularly crucial under conditions of risk and uncertainty (Lee \& Turban, 2001). Trust deficiency remains the main cause that makes people disinclines to engage in online transactions (Grabner-Kraeuter, 2002). Various strategies including using signaling cues or dependence on the website's credibility were used by online advertisers to generate more trust in their adverts (Aguirre et al., 2015). Recently, much attention has been given by scholars and business practitioners towards trust in the digital business surrounding (Beldad, De Jong, \& Steehouder, 2010). Thus, understanding the attribute of online trust and its antecedents has become an imperative agenda.

Though there are various definitions of trust, however, they may be classified into two schools of thought. One defines trust as "a belief, confidence, attitude, or expectation about another party's trustworthiness" while another refers it as "a behavioral intention or behavior that reflects a reliance on a partner and involves vulnerability and uncertainty on the part of the person who trusts" (C. Chen, n.d., p. 200). One school (J. C. Anderson and Narus 2006; Crosby, Evans, and Cowles 1990) claims that the trust is a unidimensional construct while another school (McKnight, Choudhury, \& Kacmar, 2002; Morgan \& Hunt, 1994; Zaheer \& Venkatraman, 1995) claims that trust is a multidimensional 
measure. The current study defines trust as "a general trust not related to either a specific behavior of the other party or any dimensions of trust, but rather to a person's overall conception of various dimensions of another's trustworthiness" (S. C. Chen \& Dhillon, 2003, p. 201).

Existing literature has categorized the determinants of trust in various categories. For instance, Davis, Sajtos, and Chaudhri (2015) categorized the determinants of trust in mobile service advertising into four categories namely knowledge-based (i.e. brand equity, information quality, familiarity, perceived ease of use), institutional (i.e. $3^{\text {rd }}$ party assurance, structural assurance, privacy), dispositional (i.e. trusting stance, faith in humanity) and calculative trust (customization, size of vendor, reputation of vendor). Knowledge-based trust emerges through consumers' trust in information exchange between vendors and consumers while institutional trust appears from consumers' trust in the technology of the service platform that an organization believes that the control mechanisms and technological infrastructure are able to facilitate inter-organizational transactions (Davis et al., 2015). On the other hand, dispositional trust is referred as consumer's willingness to frequently depend on others in different circumstances and calculative trust emerges when consumers judge the honesty of the vendors by comparison of the benefits of the vendors' dishonest against the consequences of being caught (Davis et al., 2015).

On the contrary, C. Chen (2008) classified the determinants of trust in online travel websites into five categories namely customer characteristics (i.e., perceived risk, disposition to trust, general online experience, personal values, attitude, prior experience, age, gender, education), website attributes (i.e.the efficiency, functionality, likeability, reliability, usability), institutional-based trust (i.e. structural assurances, tangible cues, situational normality), knowledge-based trust (i.e. service quality, overall satisfaction, rate of interactions with a web site) and calculus-based trust (i.e. reputation).

Lee and Turban (2001) categorized the drivers of consumers' trust into the trustworthiness of online sellers (i.e. integrity, ability, benevolence), the trustworthiness of online shopping platform (i.e. reliability, technical competence, medium understanding) and contextual determinants (i.e. effectiveness of security infrastructure and $3^{\text {rd }}$ party certification).

Present researches have looked into the drivers of trust from the viewpoint of mobile service advertising, online travel website and Internet shopping. Their studies used constructs that are not 
context-specific to online advertising. Therefore, due to the differences between these contexts of study and the specific characteristics of online advertising, the findings from these studies are not sufficient, inaccurate, and inapplicable in the context of online advertising. Hence, there is an urgent need for a fresh investigation to obtain a thorough understanding of the trust formation mechanism in online advertising; we have integrated the ADTRUST scale with Trust Building Model as both are context-specific to the online advertising environment. In addition, the extant body of knowledge has overlooked the effects of demographics on consumers' trust-building in online advertising. Hence, demographics were incorporated into the theoretical model. Finally, because of the complexities of human decision-making processes, we argue that the linear models used in the existing studies are unable to determine the nonlinear relationships of the antecedents of trust in online advertising (Chong, 2013).

\section{Theoretical Underpinnings}

\section{Trust Building Model (TBM) and Initial Online Trust}

Koufaris and Hampton-Sosa (2004) opine that majority studies on consumers' online trust have concentrated on trust between marketers, vendors or retailers, and consumers that developed over time. Hence, initial trust that appears after consumers have a first encounter with the marketers, vendors' or retailers' web site was being focused in the current study. Trust is defined as "the willingness of the trusting party to depend or rely upon the trustee in the expectation of a certain beneficial outcome or that the trustee will not act opportunistically (Koufaris \& Hampton-Sosa, 2004, p. 378)". Trust development is a non-static process and initial trust is the first segment of trust creation that encompasses three segments namely initiating, maintaining, and dissolving trust (Lu \& Zhou, 2007). Generally, trust is classified into initial as well as continuance trust (Zhou, 2011). Initial trust is related to website and owing to the deficiency of prior experience, consumers will depend heavily on the perceptions of website quality in developing their initial trust (Read, Vance, Moody, Beckman, \& Lowry, 2008). Furthermore, studies (Y. H. Chen \& Barnes, 2007; Flavián, Guinalíu, \& Torres, 2007; Fuller, Serva, \& Benamati, 2007) have found that reputation will influence consumers' initial trust. 
The dissimilarity between initial trust and trust is due to differences in the temporal context where initial trust is related to an individual's readiness to count on a $3^{\text {rd }}$ party since the first contact (Koufaris \& Hampton-Sosa, 2004). Here, initial trust is referred to as "trust in an unfamiliar trustee, a relationship in which the actors do not yet have credible, meaningful information about, or affective bonds with, each other" (McKnight et al., 2002, p. 335). Due to its pervasiveness (Bachmann, Zaheer, McKnight, \& Chervany, 2013), initial trust is important for online advertisers as they rely heavily on web sites to show that their advertisements are reliable and trustworthy. Consumers, who for the first time, view the online ads will depend deeply on the web site quality and marketers' or retailers' reputation to develop initial trust (Harrison McKnight, Choudhury, \& Kacmar, 2002). Developing initial trust in online ads is important for marketers and retailers to keep new consumers (Koufaris \& Hampton-Sosa, 2004).

Trust-Based Model was introduced by McKnight, Choudhury, and Kacmar (2002) with two sets of factors consisting of the institution-based structural assurance of the web and the process-based vendor-specific factors of reputation and perceived website quality that will affect consumers' trusting beliefs in and trusting intentions toward an online seller which constitute trust (Rousseau, Sitkin, Burt, \& Camerer, 1998). In the initial trust phase, consumers' trusting beliefs are unattainable through personal experience with the vendors as they have not relationship history with them (Harrison McKnight et al., 2002). Instead, initial trust is formed swiftly according to whatever information is accessible and this information may normally come in the forms of small cues e.g. trustee's voice or physical appearance (Baldwin, 1992).

Perceived website quality refers to the desirable attributes of an online advertisement website as perceived by the consumers (Al-Debei, Akroush, \& Ashouri, 2015). In the online environment, consumers are unable to see the vendors and therefore the web interface will be the online storefront where first impressions are established (Harrison McKnight et al., 2002). Hence, it is reasonable that when consumers think that the website possesses high quality then the trust in the vendors' integrity, competence, and benevolence would also be high. Website information and interface design quality may promote the creation of trust among consumers (Harrison McKnight et al., 2002). 
Reputation refers to consumers assigning scores to vendors according to second-hand information about them especially during the initial trust phase (McKnight, Cummings, \& Chervany, 1998). Listening from consumers who have interacted and have a positive experience with a vendor may alleviate their risk perceptions and hence enhance their beliefs on the seller's benevolence, competence, and integrity (Harrison McKnight et al., 2002). Vendors' reputations have been considered as essential enablers for online transactions as good reputations may reduce consumers' anxiety and transaction risk (Broutsou \& Fitsilis, 2012). Moreover, a good reputation may reduce consumers' demands for credibility credentials or integrity (Constantinides, 2004). Reputation is also regarded as a key criterion for the assessment of trustworthiness (Turilli, Vaccaro, \& Taddeo, 2010).

Conversely, structural assurance is referred to as consumers' belief that the web has technological structures or legal protection that warrant the safety and security of web business ( $\mathrm{H}$. Wang \& $\mathrm{Hu}$, 2009). However, since online advertising is regarded as one of the components of online marketing strategy that online advertisers use to promote their images, goods, and services (Aqsa \& Risal, 2015), therefore legal protection or technological structures are not relevant in enhancing consumers' trust towards online advertising. Furthermore, H. W. Kim and Gupta (2009) assert that structural assurance is ineffective in developing trust among online consumers even though it is a crucial condition for online business. Based on these justifications, the focus was put on reputation and website quality which are directly related to the context of the study.

Trust based model has been applied in several studies in various contexts of study including buying behavior in electronic retailing (Ambrose, Johnson, Ambrose, \& Johnson, 1998), e-commerce (Birkhofer, Marcus Schögel, 2000), Internet banking adoption (Alsajjan, 2009) and behavioral intention (Wu \& Tsang, 2008) and trust (Wu, Chen, \& Chung, 2010) in virtual communities.

\section{ADTRUST scale}

ADTRUST scale was introduced by Soh, Reid, and King (2009) as a standardized advertising measure to gauge the multidimensional construct of trust. It is a 20 -item Likert scale with the dimensions of affect, reliability, willingness to rely on, and usefulness. These dimensions denote consumers' affect towards advertising, their willingness to depend on advertising for their decision 
makings, and perceptions of usefulness as well as reliability of advertising (Soh, Reid, \& King, 2007). Affect refers to the emotional trust that represents the perception of consumers regarding the perceived likability on advertising that leads to consumer's perceived trust in advertising (Hahn, Scherer, Basso, \& Santos, 2016). Here, affect refers to the consumers' positive emotions about online advertising.

Instead, reliability refers to the degree of information conveyed by advertising that keeps its promises which also reflects its integrity and reliability (Soh et al., 2009). Usefulness is defined as the extent of consumer's perception of the information in advertising that is valuable and can be used to make purchasing decisions (Bleier \& Eisenbeiss, 2015). Here, usefulness refers to consumers' perception that advertising may serve as a reference for enhancing decision-making. Finally, Soh, Reid, and King (2007) assert that willingness to rely on refers to consumers' intentions to act according to the information carried by advertising.

The ADTRUST scale covers a wide scope and is valid for micro and macro levels of trust in numerous types of advertising, trust in an organization, or its sub-components (Soh et al., 2009). This scale has been used in mobile advertising (Gavilan, Avello, \& Abril, 2014), however, due to the mobility attributes of mobile devices that are not available in online advertising thus the outcomes from this study are inapplicable in the context of online advertising.

\section{Hypothesis and Research Model Development}

\section{Reputation}

Reputation refers to an individual assigning scores to other individuals according to second-hand information (Harrison McKnight et al., 2002). Reputation is really vital and extremely valuable when consumers have no prior experiences with the vendors (Kaabachi, Ben Mrad, \& Petrescu, 2017). The positive reputation of a vendor will promote a trusting relationship between consumers and vendors whereas a negative reputation will lead to a less trusting relationship (G. M. Agag \& El-Masry, 2017; Leong et al., 2020). If consumers have no personal experiences with the vendors, then reputation will be an important factor as listening from consumers who have positive experience with a vendor may remove their perceptions of risk and insecurity towards the vendor because this would promote 
consumers' beliefs about vendors' competence, integrity, and benevolence (Harrison McKnight et al., 2002). Consumers' trust towards a vendor will increase significantly if the reputation is good (Koufaris \& Hampton-Sosa, 2004). Vendors' reputations have been regarded as an imperative factor that leads to the development of consumers' trust (G. M. Agag \& El-Masry, 2017). Furthermore, consumers who have no experience with online vendors depend heavily on the reputation of these vendors so as to evaluate the trustworthiness of the vendors (Y. H. Chen \& Barnes, 2007). Generally, consumers believe that vendors with an established positive reputation will be reluctant to act in a dishonest, disreputable, or unfair way as this will risk their reputation building investments (Telser, 2002). Harrison McKnight, Choudhury, and Kacmar (2002) found that reputation has an effect on trusting intentions and beliefs toward a vendor. If other consumers have beliefs that the vendor has a particular level of fairness, honesty, and integrity, then a potential consumer will accept those qualities and utilize them to ascertain the level of trust toward the vendor (Koufaris \& Hampton-Sosa, 2004). Consumers' trust will increase substantially when a vendor is perceived to possess a good reputation (Broutsou \& Fitsilis, 2012). Reputation is second-hand information regarding a vendor's characteristics and is an imperative cue for consumers to develop trust and the reputation's effect on trust is more obvious when consumers have no direct experiences with the vendors (Lu \& Zhou, 2007). Reputation has positive effects on online initial trust in the perspective of online shopping (Hsu, Chang, Chu, \& Lee, 2014), mobile payment (Zhou, 2014), online banking (Nienaber, Hofeditz, \& Searle, 2014), mobile banking (Montazemi \& Qahri-Saremi, 2015; Zhou, 2012), Internet-only bank (Kaabachi et al., 2017), online tourism (G. M. Agag \& El-Masry, 2017) and chain restaurant (Han, Nguyen, \& Lee, 2015). Thus, we postulate the hypothesis as:

H1. Reputation significantly influences trust in online advertising

\section{Website quality}

During initial trust creation, the basis of trusting beliefs cannot be individual experiences because of lack of relationship history but instead, initial trust is swiftly formed based on whatever information that is obtainable (Harrison McKnight et al., 2002). A website is the primary communication platform between consumers and vendors (G. M. Agag \& El-Masry, 2017), and thus 
its plays a pivotal role in online commerce (Hsu, Chang, \& Chuang, 2015). Since online consumers seldom contact directly with the vendors thus they depend solely on the information of the vendor's web interface to form their expectations on the trustworthiness of the vendor (Culnan \& Armstrong, 2008). Hence, website quality will be the signal for consumers on the quality of products from the vendor (Rao, Qu, \& Ruekert, 2006; Spence, 2006). Website quality is beneficial in the formation of initial trust especially if consumers got no past experiences or interactions with the online vendor (McKnight et al., 1998; Mcknight, Kacmar, \& Choudhury, 2004; Pavlou \& Gefen, 2004). In the online setting, vendors are faceless therefore web site interface is the "online storefront" which consumers form their first impression and when they perceive the web site to have a good quality, they will have a strong trusting belief about the benevolence, integrity and competence of the vendors (Harrison McKnight et al., 2002). Previous studies have identified various website qualities including usability, trust-building technologies, ease of use, emotional appeal, and aesthetics (Gregg \& Walczak, 2010). If a website is responsive, reassuring, empathic, secure, and safe; consumers will develop a positive impression and eventually trust the website (G. M. Agag \& El-Masry, 2017). Researches have unveiled that website quality significantly influences trust in the contexts of e-commerce (Harrison McKnight et al., 2002), online merchants (McKnight et al., 1998; Mcknight et al., 2004; Pavlou \& Gefen, 2004), online company (Gefen, Karahanna, \& Straub, 2017; Harrison McKnight et al., 2002; Koufaris \& Hampton-Sosa, 2004), online bookstore (Xu, Kim, \& Koh, 2018), tourism and hospitality (Filieri, Alguezaui, \& McLeay, 2015; Sun, Wang, Shen, \& Zhang, 2015). Therefore, we anticipate that website quality will significantly influence online advertising.

H2. Website quality significantly influences trust in online advertising.

Affect

Generally, affect is the emotional trust that reflects an individual's attitude towards advertising (Soh et al., 2009). In terms of advertising, affect refers to an individual's perception pertaining to the perceived likability on advertising that may lead to perceived trust in advertising (Hahn et al., 2016). Here, affect is referred to as the factor influences online consumers' positive emotions towards online advertising. A study has shown a significant link between trust and emotional response to 
advertisements whereby consumers will trust an advertisement when they are willing to interact with the advertisements on the corporate websites (Hahn et al., 2016). Abayi and Khoshtinat (2016) opined that consumers' trust in advertising will be boosted when their emotions are directed, stimulated, and motivated by the advertisement. Therefore, we expect that if the extent of affect is high, the degree of trust will increase. Our hypothesis is:

H3. Affect has a significant influence on trust in online advertising.

\section{Reliability}

Reliability is considered as one of the cognitive trust and is referred to as the extent of information conveyed by advertising in fulfilling its promises that is an attribute of reliability and integrity (Soh et al., 2009). Consumers will feel that the advertisements are trustable when the disclosed information is honest, true, and value-oriented (Vilčeková, 2016). In addition, when consumers perceive that the advertisements are informative, pleasant, and trustable; they will gain positive attitudes toward the advertisements (Yang, Huang, Yang, \& Yang, 2017). Therefore, we anticipate that when the degree of trust in online advertising will be impacted by the perception of reliability and hence we hypothesize that:

H4. Reliability significantly influences trust in online advertising.

\section{Usefulness}

Andaleeb and Anwar (2018) assert that the expertise and likeability of a salesperson will significantly affect consumers' trust in the salesperson that eventually leads to strong trust towards the vendor. However, in the online context, there's no salesperson but consumers interact with a website instead. Koufaris and Hampton-Sosa (2004) opined that a likable and useful web site has a similar influence on consumers' trust beliefs and is seen as proof of a vendor's capabilities. Chow and Holden (1997) assert that believing a vendor can realize its promises is a critical factor for consumers to trust the vendor. It is anticipated that when consumers find a web site useful, they are more inclined to trust the web site's vendor (Koufaris \& Hampton-Sosa, 2004). The usability of a web site can affect consumers' trust toward the web site (Chang \& Chung, 2018). Usefulness has a significant 
impact on trust from the perspective of online traveling (G. Agag \& El-Masry, 2016b), m-banking (Chang \& Chung, 2018), and company (Koufaris \& Hampton-Sosa, 2004). With these reasons, we recommend the next hypothesis as:

H5. Usefulness has a significant influence on trust in online advertising.

\section{Willingness to rely on}

This construct refers to a volitional vulnerability where a consumer makes a conscious option to put aside uncertainties and proceed to involve in a positive rapport with a vendor (Harrison McKnight et al., 2002). Willingness to rely on is trivial and non-committal which means the consumer is willing to rely on a web vendor and incur certain relationship risks based on the vendor's advice and information sharing (McKnight \& Chervany, 2001). If a consumer is willing to rely on the web vendor by accepting the general vulnerability associated with using the web site, he or she is likely to accept the particular vulnerabilities linked to the use of the web site including adhering to vendor's sharing information, advice, and buying from the web site (Harrison McKnight et al., 2002). Abubakar and Ilkan (2016) assert that consumers may rely on information obtained from electronic word-of-mouth to perceive the trust of a travel destination. Hence, we postulate the next hypothesis as:

H6. Willingness to rely on has a significant influence on trust in online advertising.

\section{Control Variables: Age, Gender, Education, Hours Spent}

Lee and Turban (2001) assert that demographic variables can be included as control variables in studies of consumer trust. In addition, opined that demographics have a vital role in ascertaining consumers' trust towards a web site (Leong et al., 2020). Gender plays a significant part in the application and usage of technology (Shaikh \& Karjaluoto, 2014; Venkatesh \& Morris, 2000). In general, men are more eager to adopt novel technologies whereas younger generations are more eager to utilize novel technologies than the older generations (Akturan \& Tezcan, 2012). A. A. Anderson (1996) found that men interact better with technology while Korukonda (Korukonda, 2005) found that men's attitudes towards computers are more positive. Conversely, it was found that women's 
anxieties with computers are higher (Brosnan \& Thorpe, 2006). Gender also has a significant influence on trust as women perceive trust as the main issue for online transactions (Al-Gahtani, 2011). Christensen (2005) asserts that gender significantly influences trust in civil service. Likewise, S. C. Chen and Dhillon (2003) discovered that gender significantly influences consumers' trust in ecommerce.

Conversely, the negative association between adoption and age is associated with physical attributes that change over time (Wagner, Hassanein, \& Head, 2010). As claimed by Laguna and Babcock (1997, p 342) "older adults report more computer anxiety than young adults" and this has affected their intentions to adopt the new technologies. In addition, Korobili, Togia, and Malliari (2010) opined that individuals' attitudes toward computers will be more positive when they are introduced to technological gadgets at younger ages. Christensen (2005) discovered that age is the strongest and most significant antecedent for trust in local councils. Deng et al. (2018) opine that age also has a significant impact on trust towards mobile health services. Moreover, in the viewpoint of ecommerce, age also has a significant impact on consumers' trust (S. C. Chen \& Dhillon, 2003).

In terms of education, Balkish et al. (2017) opined that education significantly influences the trustworthiness of halal logo certification. In addition, Sultan et al. (2005b) discovered that the higher the educational attained, the lesser the degree of trust because for educated consumers they depend more on their own knowledge compared to the web site. Likewise, Christensen (2005) discovered that education significantly influences trust in parliament, the cabinet, and civil service. S. C. Chen and Dhillon (2003) assert that the educational level significantly influences consumers' trust in ecommerce.

Finally, Novak, Hoffman, and Yung (2003) opined that consumers' experiences in online settings are essential in ascertaining their attitude and behavior towards a web site. Trust functions differently based on consumers' state of knowledge regarding the goods and services (Sultan, Urban, Shankar, \& Bart, 2005b). Generally, the two constituents of trust are affective and cognitive trust. The cognitive trust comes from an individual's limited knowledge pertaining to the other party to form anticipations about the reaction of this party however this knowledge is insufficient to forecast that reaction with total sureness while the affective trust is partly affected by knowledge deficiency (Sultan et al., 
2005b). The knowledge-based trust will develop over time via interaction and experience (Pedersen et al., 2008). Lee and Turban (2001) assert that prior experience influences an individual's trust propensity which eventually determines online trust. Furthermore, Yoon (2002) asserts that consumers' trust toward a website is influenced by their familiarities with the web site. Jarvenpaa, Tractinsky, and Saarinen (2010) opined that trust is stimulated by consumers' past experiences with the web site. Consumers who visit a web site for long hours are more likely to gain more experiences and this can boost their confidence and ultimately built their trust towards the web site (Ganesan, 1994). Hence, based on the above justification, we anticipate that age, gender, education, and hours spent to have confounding effects on consumers' trust in online advertising. In conclusion, the following theoretical model ( Figure 2) is proposed.

\section{$<$ Figure 2 about here>}

\section{Methodology}

Data gathering and sampling procedure

The population consists of online consumers with online purchase experiences. Since the sampling frame is unavailable, therefore the nonprobability criterion sampling is used. The sampling locations are the four states with the highest internet usage as these states contribute more than half of the population of Internet adopters, and therefore it is sufficient to represent the study's population. A pretest was carried out by sending the initial survey instrument (Appendix A) for review by three academicians for content and face validity. Based on their comments and feedback, minor revisions were carried out in terms of layout and wordings. The revised instrument is then administered to fifty respondents and the result indicated that the Cronbach's alpha was above 0.50 implying sufficient construct reliability (T. S. Hew \& Kadir, 2017a). Following the feedback of the pilot test, slight revisions were performed, and in the final fieldwork; the survey was administered to five hundred respondents from the four states for a period of two weeks using the mall intercept technique (Leong, Jaafar, \& Ainin, 2018a). There were no rejected samples as the researchers have performed followups and checked the survey forms to ensure that there were no missing or incomplete responses. This is in accordance with Western et al. (2016) who assert that a 100\% response rate is achievable when the researcher conducts follow-ups effort. 


\section{Demographics profile}

The demographic details of the samples are elucidated in Table 1.

<Table 1 about here>

\section{Results}

Multivariate assumptions

In order to perform multivariate statistical tests, researchers have to ensure that the four basic assumptions of linearity of relationships, normality in distribution, multicollinearity, and homoscedasticity are attained. The following subsections address these assumptions.

\section{Normality test}

Normality was assessed through one sample Kolmogorov-Smirnov (KS) test and Table 2 indicates that the two-tailed $p$-values are below 0.05 which implies that the distribution is not normality distributed. Hence, the variance-based Partial Least Squares - Structural Equation Modelling (PLS-SEM) was adopted since it is resilient to non-normal distribution.

$<$ Table 2 about here>

\section{Linearity test}

We assessed the linearity of relationships using Analysis of Variance (ANOVA) and Table 3 implies that there are linear and nonlinear linkages among the dependent and independent variables.

$<$ Table 3 about here>

\section{Multicollinearity}

To assess the multicollinearity problem, we conducted a collinearity test and Table 4 reveals that the variance inflation factor (VIF) is below 5.0 while the tolerance is above 0.10 . Therefore, it is verified that there is no multicollinearity problem.

$<$ Table 4 about here>

\section{Homoscedasticity}

Finally, we test the homoscedasticity or homogeneity of variance using a scatter plot of regression standardized residuals and Figure 3 indicates that the residuals are distributed across a diagonal line 
uniformly (Leong, Hew, Ooi, \& Wei, 2019). Thus, we concluded that the variance is homogenous and homoscedasticity is achieved.

$<$ Figure 3 about here>

\section{Common Method Bias (CMB)}

There are possibilities of $\mathrm{CMB}$ as the outcome and predictor measures were captured through a common battery. To address this, we conducted procedural and statistical remedies. Procedurally, we have used different Likert scales to measure the responses as well as ensuring the anonymity of the respondents' identities. We also asked the respondents to answer the questions candidly and that there are no exact true or false answers to each question. In terms of statistics, we conducted Harman's single factor and common method factor to check for the presence of CMB (Leong, Hew, Ooi, \& Wei, 2019). Table 5 shows that a sole factor explicates not more than half of the overall variance indicating that $\mathrm{CMB}$ is immaterial. To further confirm this, we also perform the common method factor by changing each item into single-item second-order constructs (Figure 4) and calculate the substantive variance and method variance. Appendix B shows that most of the method loadings are insignificant with negative or negligible values while all substantive loadings are significant with large values (Leong et al., 2020). In addition, the ratio of 29:1 for the substantive to the method variance is significantly high thus confirming that CMB is not a concern (Leong et al., 2020).

$<$ Table 5 about here $>$

$<$ Figure 4 about here>

\section{Non-Response Bias}

Besides $\mathrm{CMB}$, we also compared the late and early respondents using an independent t-test to assess the non-response bias (Leong, Jaafar, \& Ainin, 2018b). Table 6 shows that the differences are insignificant and thus there is no nonresponse bias in this study.

$<$ Table 6 about here>

\section{Measurement Model}

The measurement model's (Figure 5) convergent validity and construct reliability were then evaluated (Hair, Sarstedt, \& Ringle, 2019). Table 7 implies that the composite reliability, Cronbach's alpha, and rho_A surpassed 0.70, therefore, the constructs are indeed reliable (T. S. Hew \& Kadir, 
2016; Leong, Hew, Ooi, \& Wei, 2019). Moreover, the average variance extracted has superseded 0.50 verifying convergent validity of the measures (J. J. Hew, Leong, Tan, Ooi, \& Lee, 2019; K. Kim \& Kim, 2011; Riquelme, Román, Cuestas, \& Iacobucci, 2019).

$<$ Figure 5 about here>

$<$ Table 7 about here>

\section{Discriminant validity}

The discriminant validity was examined using "Fornell-Larcker's criterion test" (Guan \& Lam, 2019; Jeon, Son, Chung, \& Drumwright, 2019; Wong, Leong, Hew, Tan, \& Ooi, 2019) and Table 8 indicates that the correlation coefficients are smaller than the square root of AVE (T. S. Hew \& Kadir, 2017b). We also examined the cross-loadings (Appendix C) and found that all loadings loaded strongly to their related constructs and load poorly to unrelated constructs (J. J. Hew, Leong, Tan, Lee, \& Ooi, 2018). Further confirmation using the Hetero-Trait-Mono-Trait (HTMT) ratio (Table 9) also confirmed that discriminant validity was achieved based on the HTMT ratio of less than 0.90 .

$<$ Table 8 about here>

$<$ Table 9 about here>

\section{$R$-square}

The measurement model has strong predictive power as the R-square is 0.751 (Table 10) which indicates that the research model may elucidate $75.1 \%$ of the overall variance in consumers' trust in online advertising.

\section{<Table 10 about here>}

\section{Structural Model}

When the quality of the measurement model was evaluated, we continued with stage two by assessing the structural model (Figure 6). Following the structural path analysis (Table 11), we discovered that 6 out of 10 paths are significant. More specifically, affective $(\beta=-0.138, p<0.001)$, hours spent $(\beta=0.082, p<0.001)$, reliability $(\beta=0.438, p<0.001)$, reputation $(\beta=0.178, p<0.001)$, website quality $(\beta=0.366, p<0.001)$ and willingness to rely on $(\beta=0.144, p<0.001)$ have significant impacts on trust in online advertising. Nevertheless, there are no significant effects of age 
$(\beta=0.010, p>0.05)$, education $(\beta=0.022, p>0.05)$, gender $(\beta=-0.039, p>0.05)$ and usefulness $(\beta$ $=-0.001, p>0.05)$ on trust in online advertising.

<Figure 6 about here>

$<$ Table 11 about here>

Artificial Neural Network (ANN)

Although Partial Least Squares (PLS) is vigorous against distribution that is non-normal, however, it is not able to capture nonlinear relationships. Therefore to address this, we have used a two-staged Partial Least Squares-Artificial Neural Network (PLS-ANN) analysis to rank the significant variables' normalized importance (Leong, Hew, Ooi, \& Lin, 2019). There is an increasing application of ANN models in assisting decision making in numerous areas including retailing, marketing, and manufacturing (Agrawal \& Schorling, 1996). ANN entails the input, hidden, and output layers. Similar to Leong, Hew, Ooi, and Wei (2019), multilayer perceptrons were used with a "feed-forwardback-propagation" algorithm where the significant predictors from PLS path analysis are used as the input neurons (Figure 7). To elude over-simplification, we engaged, 10-fold cross-validation with ten ANN networks. We used the sigmoid function to activate the output and hidden layer. The quantum of hidden nodes is spontaneously computed by the SPSS neural network module. The ANN network structure consists of one hidden layer with 4 hidden nodes. We partitioned the data into $90 \%$ for training and $10 \%$ for testing.

$<$ Figure 7 about here>

The PLS-ANN approach is a novel analytical method in expert systems and artificial intelligence (AI). This approach has several advantages compared to the existing multivariate regression approach which can only test for linear and compensatory models. However, the ANN model is able to detect both linear and nonlinear as well as non-compensatory models, and furthermore, it can learn from the deep learning training session. In fact, ANN is a type of machine learning (ML) because it is able to reduce the number of errors using a feed-forward-back-propagation (FFBP) algorithm. Nevertheless, due to its "black box" operation, ANN is not suitable for hypothesis testing. Hence, by using an integrated PLS-ANN approach, we are able to complement and take advantage of the strengths of both methods and therefore advances the expert systems and artificial intelligence methodology. 
To measure the ANN model's goodness-of-fit, the root-mean-square-of-error (RMSE) was calculated and Table 12 implies that the RMSE figures for both testing and training sessions are relatively small. Hence, there is an excellent goodness-of-fit. Following the value of the R-square calculated from the RMSE values, the ANN model is able to predict trust in online advertising with an accuracy of $76.14 \%$.

<Table 12 about here>

Finally, the normalized importance was computed via sensitivity analysis where the relative importance was divided by the biggest relative importance and presented as a percentage. Table 13 indicates that reliability $(100 \%)$ is the most significant predictor follows by website quality $(66.68 \%)$, willingness to rely on (47.51\%), reputation (42.58\%), affective (35.52\%) and hours spent (17.44\%).

<Table 13 about here>

\section{Discussion}

According to the outcomes of the PLS path analysis, affect significantly influences trust in online advertising. This is a new discovery because previously there is no study on this relationship in the extant literature. The finding reveals that there is empirical evidence to support that affect in the form of consumers' positive emotions will directly affects the level of trust towards online advertising. However, it is interesting that this is a negative effect which means that high affect will lead to lower trust. Owing to this, more researches should be carried out to further examine and confirm this relationship.

Reliability has a significant effect on trust and this is another new association. It indicates that consumers' trust in online advertising is indeed influenced by the perceptions of how reliable the adverts are. If they feel that the adverts are trustable and reliable with honesty in disclosed information then they will perceive the advert as trustable. Similarly, reputation significantly influences trust in online advertising. This is in line with the outcomes of the existing related studies (G. M. Agag \& El-Masry, 2017; Broutsou \& Fitsilis, 2012; Han et al., 2015; Kaabachi et al., 2017; J. B. Kim, 2012; Meng-Hsiang, Li-Wen, \& Cheng-Se, 2014; Montazemi \& Qahri-Saremi, 2015; Nienaber et al., 2014; Zhou, 2012, 2014). Nevertheless, the finding has proffered new empirical evidence from the context of trust in online advertising which has been overlooked previously. It 
indicates that consumers will trust more in online advertising if the reputations of the vendors are good.

Surprisingly, usefulness has an insignificant influence on trust in online advertising. This is contradicting existing related studies (G. Agag \& El-Masry, 2016a, 2016b; Chang \& Chung, 2018; Koufaris \& Hampton-Sosa, 2004) which show that usefulness significantly influences trust. However, we argue that due to differences in terms of contexts of study, the contrary finding is justifiable as consumers in the context of online advertising have different perceptions and behave differently from consumers in the contexts of online travel and m-banking. Nevertheless, the finding is useful as it has given a novel empirical evidence to support that usefulness has no role to play in building consumers' trust in online advertising. But it does not mean that vendors should reduce their effort in further strengthening the usefulness of the online adverts but instead they may use the existing approach and maintain their effort in ensuring that consumers' trusts remain unchanged.

Website quality is another significant driver of trust in online advertising. This outcome is in line with existing studies (Filieri et al., 2015; Gefen et al., 2017; M. J. Kim, Chung, \& Lee, 2011; M. J. Kim, Chung, Lee, \& Preis, 2016; McKnight et al., 2002; Mcknight et al., 2004; Pavlou \& Gefen, 2004; C. W. Wang, Ho, Chan, \& Tse, 2015; Xu et al., 2018). The contrasting finding may be owing to differences in contexts of study because prior researches were conducted in the context of tourism and hospitality, online bookstore, online merchants and companies, and e-commerce. Nevertheless, the context of online advertising is considerably different from these contexts and therefore the findings from the previous studies are not applicable to the current context.

Likewise, the willingness to rely on influences trust in online advertising. This represents a new discovery and has proffered new evidence to theorize that when consumers are willing to rely on the online adverts and put aside their doubts and proceed to build positive relationships with the vendors then their trust towards the online advertising will be more. Previously there has been no study that examines this relationship and therefore the new finding makes a significant contribution in advancing our understanding of the role of willingness to rely on toward trust in online advertising.

Finally, in terms of demographic control variables, only hours spent has an effective confounding effect on trust in online advertising but not age, gender, and education. This is interesting as previous 
studies only validated that prior experience significantly influences trust and this is perhaps the first time that research has validated that the time spent online also significantly influences trust toward online advertising. In addition, the finding also provided empirical evidence that gender, education, and age have no role in enhancing consumers' trust in online adverts.

\section{Theoretical Contributions}

The research has some essential theoretical contributions. Firstly, it has successfully integrated the trust-building model with the ADTRUST model. With the integrated model, it has proffered a novel framework in understanding the antecedents of consumers' trust in online advertising. With this new integrated theory, researchers and scholars may gain a clearer understanding of the mechanism that builds trust among consumers of online advertising.

Secondly, it has also validated the relationships between website quality, reputation, and trust in online advertising. Previously there has been no research that studied these associations and with the newly validated relationships, scholars and researchers will be able to expand these relationships to other contexts of study.

Third, the study also validated relationships between reliability, usefulness affect, and willingness to rely on with trust in online advertising. It is perhaps the first time that the constructs of ADTRUST were used to predict consumers' trust in online advertising. These are new relationships that have not been validated in the current context and therefore the finding has provided a new theory on the effects of ADTRUST constructs in building consumers' trust toward online advertising.

Fourth, the incorporation of the demographic control variable of age, gender, education, and hours spent, the study has also proffered a novel theoretical implication to the existing research. Prior studies did not examine the impacts of these variables in the viewpoint of online advertising and thus the study as provided a solid ground for scholars and researchers to further examine their effects in other related contexts of study in the future.

Last but not least, with the application of the SEM-ANN analysis that can capture both linear and nonlinear relationships (Leong et al., 2020), this study has proffered a novel research methodology in terms of consumers' trust in online advertising for scholars and researchers. The new approach can be 
used as a guideline for other contexts of research as it can address the issues of complexity and oversimplification of consumers' decision making processes as well as issues pertaining to the noncompensatory model where the effect of one factor cannot be compensated by other factors based on a linear regression or structural equation.

\section{Managerial Contributions}

There are several managerial contributions. First, reliability is the utmost important predictor for consumers' trust in online advertising. Hence, online marketers, advertisers, and website service providers should always bear in mind that the information in the online adverts is reliable and trustable. To do this, they may consider using online surveys to measure the level of reliability among consumers, and based on the feedbacks necessary steps and measures can be taken to further improve the level of reliability. In addition, they can also upgrade the hardware and software of the online system so that there will be no system downs or unexpected interruptions to ensure that the system is always reliable.

Secondly, since website quality is the second most powerful antecedent of consumers' trust in online advertising, therefore, website service providers may concentrate on strengthening the quality of the websites to ensure that there will be zero defects in terms of the accuracy of the information, punctuality in service deliveries, immediate responses to complaints and queries, real-time customer services, user-friendly interfaces, and International Organization for Standardization (ISO) quality assurance. A special task force can also be engaged to focus on raising the quality of the website while a response team can be formed to handle any unexpected happenings so that contingency measures can be taken as soon as possible and service quality as always maintained.

Third, willingness to rely on the online adverts should also be given appropriate attention as it is the third strongest predictor of trust. For this reason, online marketers and advertisers may ascertain that the content of the website is free of any doubts so that consumers are willing to rely on the content. For example, online advertisers may consider establishing a special unit in data and information validation in terms of accuracy and dependency. In addition, they can also provide more guarantees in the context of the quality and effectiveness of the online adverts to further boost their 
confidence. More protections can also be given so that consumers will be less worry and thus are willing to rely on using online advertising services.

Next, online advertising service providers must ensure that their reputations are not tarnished. To do this, they must ensure that a good reputation is always maintained through various platforms be it printed or not printed mediums. One option is to use social media to propagate their corporate social responsibility (CSR). In addition, they can also use traditional billboards, newspapers, TVs, radios, magazines, banners and etc. to show their good deeds. Another option is to engage spoke persons with good images to promote their good deeds.

In terms of affect, online advertising service providers need to ensure that consumers are able to feel the positive emotions that exist in the online adverts. To cater to this, they should ensure that positive elements are used in their online adverts while eliminating any negative or sensitive elements. For example, positive values and messages can be incorporated into the online adverts either directly or indirectly through the use of photos, videos, audios, cartoons, animations, emoji or emoticon faces and etc. A sense of happiness and joy must always be a factor to consider when designing the online adverts so that consumers will be motivated, stimulated, directed, and sense the feel-good elements when reading the online adverts.

Finally, in order to prolong the time spent that can boost consumers' trust, online advertising service providers may think of using state-of-the-art technologies e.g. virtual reality to improve the appearance and attractiveness of the online adverts. In addition, they can also provide other attractions such as instant gifts of discounts or vouchers that pop up from time to time when consumers are reading the online adverts. Besides, incentives can be given for consumers who have read and clicked some special buttons that can further delay their time in reading the online adverts.

\section{Conclusion}

The study has successfully integrated the trust-building model with the constructs from ADTRUST using an SEM-ANN analysis to predict trust in online advertising. This is a new approach as a dual-theory dual-stage approach was engaged to comprehend the mechanism of consumers' trust- 
building in online advertising. With the new approach, researchers and scholars will be able to obtain a clearer understanding of consumers' trust from the context of online advertising.

\section{Research Limitations and Future Directions}

Among the limitations include (1) the findings were confined to the Malaysian perspective and therefore may not be extended to other regions (2) a cross-sectional approach means that we are unable to examine the temporal effect and (3) the ANN model cannot explain $100 \%$ trust in online advertising as the research model is limited to integration of just two theories. Hence, future studies may consider (1) conducting a new study in other geographical regions (2) use longitudinal study to examine the temporal effect and (3) include more theories or constructs to raise the predictive power of the research model.

\section{References}

Abayi, M., \& Khoshtinat, B. (2016). Study of the Impact of Advertising on Online Shopping Tendency for Airline Tickets by Considering Motivational Factors and Emotional Factors. Procedia Economics and Finance, 36, 532-539. https://doi.org/10.1016/s2212-5671(16)30065-x

Abubakar, A. M., \& Ilkan, M. (2016). Impact of online WOM on destination trust and intention to travel: A medical tourism perspective. Journal of Destination Marketing and Management, 5(3), 192-201. https://doi.org/10.1016/j.jdmm.2015.12.005

Agag, G., \& El-Masry, A. A. (2016a). Understanding consumer intention to participate in online travel community and effects on consumer intention to purchase travel online and WOM: An integration of innovation diffusion theory and TAM with trust. Computers in Human Behavior, 60(March), 97-111. https://doi.org/10.1016/j.chb.2016.02.038

Agag, G., \& El-Masry, A. A. (2016b). Understanding the determinants of hotel booking intentions and moderating role of habit. International Journal of Hospitality Management, 54, 52-67. https://doi.org/10.1016/j.ijhm.2016.01.007

Agag, G. M., \& El-Masry, A. A. (2017). Why Do Consumers Trust Online Travel Websites? Drivers and Outcomes of Consumer Trust toward Online Travel Websites. Journal of Travel Research, 
56(3), 347-369. https://doi.org/10.1177/0047287516643185

Agrawal, D., \& Schorling, C. (1996). Market share forecasting: An empirical comparison of artificial neural networks and multinomial logit model. Journal of Retailing, 72(4), 383-407. https://doi.org/10.1016/S0022-4359(96)90020-2

Aguirre, E., Mahr, D., Grewal, D., de Ruyter, K., \& Wetzels, M. (2015). Unraveling the personalization paradox: The effect of information collection and trust-building strategies on online advertisement effectiveness. Journal of Retailing, 91(1), 34-49. https://doi.org/10.1016/j.jretai.2014.09.005

Akturan, U., \& Tezcan, N. (2012). Mobile banking adoption of the youth market: Perceptions and intentions. Marketing Intelligence and Planning, 30(4), 444-459. https://doi.org/10.1108/02634501211231928

Al-Debei, M. M., Akroush, M. N., \& Ashouri, M. I. (2015). Consumer attitudes towards online shopping: The effects of trust, perceived benefits, and perceived web quality. Internet Research, 25(5), 707-733. https://doi.org/10.1108/IntR-05-2014-0146

Al-Gahtani, S. S. (2011). Modeling the electronic transactions acceptance using an extended technology acceptance model. Applied Computing and Informatics, 9(1), 47-77. https://doi.org/10.1016/j.aci.2009.04.001

Alsajjan, B. a. (2009). The relative importance of trust intentions and trust beliefs in internet banking adoption. International Review of Business Research Papers, 5(5), 257-272.

Ambrose, P., Johnson, G., Ambrose, P. J., \& Johnson, G. J. (1998). A trust model of buying behaviour in electronic retailing. Electronic Retailing, 262-265. Retrieved from http://aisel.aisnet.org/amcis1998

Andaleeb, S. S., \& Anwar, S. F. (2018). Factors Influencing Customer Trust in Salespersons in a Developing Country. Journal of International Marketing, 4(4), 35-52. https://doi.org/10.1177/1069031x9600400404

Anderson, A. A. (1996). Predictors of computer anxiety and performance in information systems. Computers in Human Behavior, 12(1), 61-77. https://doi.org/10.1016/0747-5632(95)00019-4 Anderson, J. C., \& Narus, J. A. (1990). A Model of Distributor Firm and Manufacturer Firm Working 
Partnerships. Journal of Marketing, 54(1), 42. https://doi.org/10.2307/1252172

Aqsa, M., \& Risal, M. (2015). The Influence of Online Advertisement on Consumer Attitudes. First International Conference on Economics and Banking, 33-38. https://doi.org/10.2991/iceb15.2015 .6

Bachmann, R., Zaheer, A., McKnight, D. H., \& Chervany, N. L. (2013). Reflections on an Initial Trust-Building Model. In Handbook of Trust Research. https://doi.org/10.4337/9781847202819.00008

Baldwin, M. W. (1992). Relational schemas and the processing of social information. Psychological Bulletin, 112(3), 461-484. https://doi.org/10.1037/0033-2909.112.3.461

Balkish, N., Universiti, Z., Mara, T., Mohamed, R., Universiti, Y., Mara, T., \& Kasim, S. S. (2017). The Effect of Consumers' Interest, Information Access and Spending Willingness on Halal ... Asia-Pacific Management Accounting Journal, 12(December), 1-15.

Beldad, A., De Jong, M., \& Steehouder, M. (2010). How shall i trust the faceless and the intangible? A literature review on the antecedents of online trust. Computers in Human Behavior, 26(5), 857-869. https://doi.org/10.1016/j.chb.2010.03.013

Birkhofer, Marcus Schögel, B. (2000). Transaction- and Trust-Based Strategies in E-commerce - a Conceptual Approach. Electronic Markets, 10(3), 169-175. https://doi.org/10.1080/10196780050177071

Bleier, A., \& Eisenbeiss, M. (2015). The Importance of Trust for Personalized Online Advertising. Journal of Retailing, 91(3), 390-409. https://doi.org/10.1016/j.jretai.2015.04.001

Blut, M., Teller, C., \& Floh, A. (2018). Testing Retail Marketing-Mix Effects on Patronage: A MetaAnalysis. Journal of Retailing, 94(2), 113-135. https://doi.org/10.1016/j.jretai.2018.03.001

Brosnan, M. J., \& Thorpe, S. J. (2006). An evaluation of two clinically-derived treatments for technophobia. Computers in Human Behavior, 22(6), 1080-1095. https://doi.org/10.1016/j.chb.2006.02.001

Broutsou, A., \& Fitsilis, P. (2012). Online Trust: The Influence of Perceived Company’s Reputation on Consumers' Trust and the Effects of Trust on Intention for Online Transactions. Journal of Service Science and Management, 05(04), 365-372. https://doi.org/10.4236/jssm.2012.54043 
Chang, K., \& Chung, N. (2018). Interacting with Computers Understanding factors affecting trust in and satisfaction with mobile banking in Korea: A modified DeLone and McLean's model perspective. Interacting with Computers, 21(5-6), 385-392. https://doi.org/10.1016/j.intcom.2009.06.004

Chen, C. (n.d.). Identifying Significant Factors Influencing Consumer Trust in an Online Travel Site. Information Technology \& Tourism, 8(3-4), 197-214. https://doi.org/10.3727/109830506778690849

Chen, S. C., \& Dhillon, G. S. (2003). Interpreting Dimensions of Consumer Trust in E-Commerce. Information Technology and Management, 4(2-3), 303-318. Retrieved from http://link.springer.com/article/10.1023/A\%3A1022962631249\%5Cnpapers3://publication/doi/1 0.1023/A:1022962631249

Chen, Y. H., \& Barnes, S. (2007). Initial trust and online buyer behaviour. Industrial Management and Data Systems, 107(1), 21-36. https://doi.org/10.1108/02635570710719034

Chong, A. Y. L. (2013). Predicting m-commerce adoption determinants: A neural network approach. Expert Systems with Applications, 40(2), 523-530. https://doi.org/10.1016/j.eswa.2012.07.068

Chow, S., \& Holden, R. (1997). Toward An Understanding Of Loyalty: The Moderating Role Of Trust. Journal of Managerial Issues, 9(3), 275-298.

Christensen, T. (2005). Christensen and Laegreid / TRUST IN GOVERNMENT 487 TRUST IN GOVERNMENT The Relative Importance of Service Satisfaction, Political Factors, and Demography. Public Performance \& Management Review, 28(4), 487-511. https://doi.org/10.1080/15309576.2005.11051848

Constantinides, E. (2004). Influencing the online consumer's behavior: The Web experience. Internet Research, 14(2), 111-126. https://doi.org/10.1108/10662240410530835

Crosby, L. A., Evans, K. R., \& Cowles, D. (1990). Relationship Quality in Services Selling: An Interpersonal Influence Perspective. Journal of Marketing, 54(3), 68-81. https://doi.org/10.1177/002224299005400306

Culnan, M. J., \& Armstrong, P. K. (2008). Information Privacy Concerns, Procedural Fairness, and Impersonal Trust: An Empirical Investigation. Organization Science, 10(1), 104-115. 
https://doi.org/10.1287/orsc.10.1.104

Davis, R., Sajtos, L., \& Chaudhri, A. A. (2015). Do Consumers Trust Mobile Service Advertising? Contemporary Management Research, 7(4), 245-270. https://doi.org/10.7903/cmr.9696

Deng, Z., Hong, Z., Ren, C., Zhang, W., \& Xiang, F. (2018). What predicts patients' adoption intention toward mHealth services in China: Empirical study. Journal of Medical Internet Research, 20(8), e172. https://doi.org/10.2196/mhealth.9316

Filieri, R., Alguezaui, S., \& McLeay, F. (2015). Why do travelers trust TripAdvisor? Antecedents of trust towards consumer-generated media and its influence on recommendation adoption and word of mouth. Tourism Management, 51, 174-185. https://doi.org/10.1016/j.tourman.2015.05.007

Flavián, C., Guinalíu, M., \& Torres, E. (2007). The influence of corporate image on consumer trust. Internet Research, 15(4), 447-470. https://doi.org/10.1108/10662240510615191

Fuller, M. A., Serva, M. A., \& Benamati, J. (2007). Seeing is believing: The transitory influence of reputation information on E-Commerce trust and decision making: Research Note. Decision Sciences, 38(4), 675-699. https://doi.org/10.1111/j.1540-5915.2007.00174.x

Ganesan, S. (1994). Determinants of Long-Term Orientation in Buyer-Seller Relationships. Journal of Marketing, 58(2), 1-19. https://doi.org/10.1177/002224299405800201

Gavilan, D., Avello, M., \& Abril, C. (2014). The mediating role of mental imagery in mobile advertising. International Journal of Information Management, 34(4), 457-464. https://doi.org/10.1016/j.ijinfomgt.2014.04.004

Gefen, Karahanna, \& Straub. (2017). Trust and TAM in Online Shopping: An Integrated Model. MIS Quarterly, 27(1), 51-90. https://doi.org/10.2307/30036519

Grabner-Kraeuter, S. (2002). The role of consumers trust in online-shopping. Journal of Business Ethics, 39(1-2), 43-50. https://doi.org/10.1023/A:1016323815802

Gregg, D. G., \& Walczak, S. (2010). The relationship between website quality, trust and price premiums at online auctions. Electronic Commerce Research, 10(1), 1-25. https://doi.org/10.1007/s10660-010-9044-2

Guan, C., \& Lam, S. Y. (2019). Product Rating Statistics as Consumer Search Aids. Journal of 
Interactive Marketing, 48(November 2019), 51-70. https://doi.org/10.1016/j.intmar.2019.02.003

Ha, L. (2008). Online advertising research in advertising journals: A review. Journal of Current Issues and Research in Advertising, 30(1), 31-48.

https://doi.org/10.1080/10641734.2008.10505236

Hahn, I., Scherer, F., Basso, K., \& Santos, M. (2016). Consumer Trust in and Emotional Response to Advertisements on Social Media and their Influence on Brand Evaluation. Brazilian Business Review, 13(4), 49-71. https://doi.org/10.15728/bbr.2016.13.4.3

Hair, J. F., Sarstedt, M., \& Ringle, C. M. (2019). Rethinking some of the rethinking of partial least squares. European Journal of Marketing, 53(4), 566-584. https://doi.org/10.1108/EJM-10-20180665

Han, S. H., Nguyen, B., \& Lee, T. J. (2015). Consumer-based chain restaurant brand equity, brand reputation, and brand trust. International Journal of Hospitality Management, 50, 84-93. https://doi.org/10.1016/j.ijhm.2015.06.010

Harrison McKnight, D., Choudhury, V., \& Kacmar, C. (2002). The impact of initial consumer trust on intentions to transact with a web site: A trust building model. Journal of Strategic Information Systems, 11(3-4), 297-323. https://doi.org/10.1016/S0963-8687(02)00020-3

Hew, J. J., Leong, L. Y., Tan, G. W. H., Lee, V. H., \& Ooi, K. B. (2018). Mobile social tourism shopping: A dual-stage analysis of a multi-mediation model. Tourism Management, 66(June 2018), 121-139. https://doi.org/10.1016/j.tourman.2017.10.005

Hew, J. J., Leong, L. Y., Tan, G. W. H., Ooi, K. B., \& Lee, V. H. (2019). The age of mobile social commerce: An Artificial Neural Network analysis on its resistances. Technological Forecasting and Social Change, 144(July 2019), 311-324. https://doi.org/10.1016/j.techfore.2017.10.007

Hew, T. S., \& Kadir, S. L. S. A. (2016). Predicting instructional effectiveness of cloud-based virtual learning environment. Industrial Management and Data Systems, 116(8), 1557-1584. https://doi.org/10.1108/IMDS-11-2015-0475

Hew, T. S., \& Kadir, S. L. S. A. (2017a). Applying Channel Expansion and Self-Determination Theory in predicting use behaviour of cloud-based VLE. Behaviour and Information Technology, 36(9), 875-896. https://doi.org/10.1080/0144929X.2017.1307450 
Hew, T. S., \& Kadir, S. L. S. A. (2017b). The drivers for cloud-based virtual learning environment: Examining the moderating effect of school category. Internet Research, 27(4), 942-973. https://doi.org/10.1108/IntR-08-2016-0256

Hsu, M. H., Chang, C. M., Chu, K. K., \& Lee, Y. J. (2014). Determinants of repurchase intention in online group-buying: The perspectives of DeLone \& McLean is success model and trust. Computers in Human Behavior, 36, 234-245. https://doi.org/10.1016/j.chb.2014.03.065

Hsu, M. H., Chang, C. M., \& Chuang, L. W. (2015). Understanding the determinants of online repeat purchase intention and moderating role of habit: The case of online group-buying in Taiwan. International Journal of Information Management, 35(1), 45-56. https://doi.org/10.1016/j.ijinfomgt.2014.09.002

IndustryARC. (2019). Online Advertising Market - Industry Analysis, Market Size, Share, Trends, Application Analysis, Growth and Forecast 2019 - 2025. Retrieved from https://industryarc.com/Research/Online-Advertising-Market-Research-500626

Jarvenpaa, S. L., Tractinsky, N., \& Saarinen, L. (2010). Consumer Trust in an Internet Store: A CrossCultural Validation. Journal of Computer-Mediated Communication, 5(2), 0-0. https://doi.org/10.1111/j.1083-6101.1999.tb00337.x

Jeon, Y. A., Son, H., Chung, A. D., \& Drumwright, M. E. (2019). Temporal Certainty and Skippable In-Stream Commercials: Effects of Ad Length, Timer, and Skip-ad Button on Irritation and Skipping Behavior. Journal of Interactive Marketing, 47(August 2019), 144-158. https://doi.org/10.1016/j.intmar.2019.02.005

Kaabachi, S., Ben Mrad, S., \& Petrescu, M. (2017). Consumer initial trust toward internet-only banks in France. International Journal of Bank Marketing, 35(6), 903-924. https://doi.org/10.1108/IJBM-09-2016-0140

Kim, H. W., \& Gupta, S. (2009). A comparison of purchase decision calculus between potential and repeat customers of an online store. Decision Support Systems, 47(4), 477-487. https://doi.org/10.1016/j.dss.2009.04.014

Kim, J. B. (2012). An empirical study on consumer first purchase intention in online shopping: Integrating initial trust and TAM. Electronic Commerce Research, 12(2), 125-150. 
https://doi.org/10.1007/s10660-012-9089-5

Kim, K., \& Kim, J. (2011). Third-party Privacy Certification as an Online Advertising Strategy: An Investigation of the Factors Affecting the Relationship between Third-party Certification and Initial Trust. Journal of Interactive Marketing, 25(3), 145-158.

https://doi.org/10.1016/j.intmar.2010.09.003

Kim, M. J., Chung, N., \& Lee, C. K. (2011). The effect of perceived trust on electronic commerce: Shopping online for tourism products and services in South Korea. Tourism Management, 32(2), 256-265. https://doi.org/10.1016/j.tourman.2010.01.011

Kim, M. J., Chung, N., Lee, C. K., \& Preis, M. W. (2016). Dual-route of persuasive communications in mobile tourism shopping. Telematics and Informatics, 33(2), 293-308. https://doi.org/10.1016/j.tele.2015.08.009

Korobili, S., Togia, A., \& Malliari, A. (2010). Computer anxiety and attitudes among undergraduate students in Greece. Computers in Human Behavior, 26(3), 399-405. https://doi.org/10.1016/j.chb.2009.11.011

Korukonda, A. R. (2005). Personality, individual characteristics, and predisposition to technophobia: Some answers, questions, and points to ponder about. Information Sciences, 170(2-4), 309-328. https://doi.org/10.1016/j.ins.2004.03.007

Koufaris, M., \& Hampton-Sosa, W. (2004). The development of initial trust in an online company by new customers. Information and Management, 41(3), 377-397. https://doi.org/10.1016/j.im.2003.08.004

Laguna, K., \& Babcock, R. L. (1997). Computer anxiety in young and older adults: Implications for human-computer interactions in older populations. Computers in Human Behavior, 13(3), 317326. https://doi.org/10.1016/S0747-5632(97)00012-5

Lee, M. K. O., \& Turban, E. (2001). A trust model for consumer internet shopping. International Journal of Electronic Commerce, 6(1), 75-91. https://doi.org/10.1080/10864415.2001.11044227

Leong, L. Y., Hew, T. S., Ooi, K. B., \& Chong, A. Y. L. (2020). Predicting the antecedents of trust in social commerce - A hybrid structural equation modeling with neural network approach. Journal of Business Research, 110(March 2020), 24-40. 
https://doi.org/https://doi.org/10.1016/j.jbusres.2019.11.056

Leong, L. Y., Hew, T. S., Ooi, K. B., \& Lin, B. (2019). Do Electronic Word-of-Mouth and Elaboration Likelihood Model Influence Hotel Booking? Journal of Computer Information Systems, 59(2), 146-160. https://doi.org/10.1080/08874417.2017.1320953

Leong, L. Y., Hew, T. S., Ooi, K. B., \& Tan, G. W. H. (2019). Predicting actual spending in online group buying - An artificial neural network approach. Electronic Commerce Research and Applications, 38(November-December 2019), 10898. https://doi.org/10.1016/j.elerap.2019.100898

Leong, L. Y., Hew, T. S., Ooi, K. B., \& Wei, J. (2019). Predicting mobile wallet resistance: A twostaged structural equation modeling-artificial neural network approach. International Journal of Information Management, in-press(in-press). https://doi.org/10.1016/j.ijinfomgt.2019.102047

Leong, L. Y., Jaafar, N. I., \& Ainin, S. (2018a). Understanding Facebook Commerce (F-Commerce) Actual Purchase From an Artificial Neural Network Perspective. Journal of Electronic Commerce Research, 19(1), 75-103. Retrieved from http://www.jecr.org/sites/default/files/19_1Paper5.pdf

Leong, L. Y., Jaafar, N. I., \& Ainin, S. (2018b). What triggers impulse purchase in Facebook commerce? International Journal of Mobile Communications, 16(4), 459-492. https://doi.org/10.1504/ijmc.2018.092679

Liu-Thompkins, Y. (2019). A Decade of Online Advertising Research: What We Learned and What We Need to Know. Journal of Advertising, 48(1), 1-13. https://doi.org/10.1080/00913367.2018.1556138

Lu, Y., \& Zhou, T. (2007). A research of consumers' initial trust in online stores in China. Journal of Research and Practice in Information Technology, 39(3), 167-180.

McKnight, D. H., \& Chervany, N. L. (2001). What trust means in e-commerce customer relationships: An interdisciplinary conceptual typology. International Journal of Electronic Commerce, 6(2), 35-59. https://doi.org/10.1080/10864415.2001.11044235

McKnight, D. H., Choudhury, V., \& Kacmar, C. (2002). Developing and validating trust measures for e-commerce: An integrative typology. Information Systems Research, 13(3), 334-359. 
https://doi.org/10.1287/isre.13.3.334.81

McKnight, D. H., Cummings, L. L., \& Chervany, N. L. (1998). Initial trust formation in new organizational relationships. Academy of Management Review, 23(3), 473-490. https://doi.org/10.5465/AMR.1998.926622

Mcknight, D. H., Kacmar, C. J., \& Choudhury, V. (2004). Shifting Factors and the Ineffectiveness of Third Party Assurance Seals: A Two-Stage Model of Initial Trust in a Web Business. Electronic Markets, 14(3), 252-266. https://doi.org/10.1080/1019678042000245263

Meng-Hsiang, H., Li-Wen, C., \& Cheng-Se, H. (2014). Understanding online shopping intention: the roles of four types of trust and their antecedents. Internet Research, 24(3), 332-352. https://doi.org/10.1108/IntR-01-2013-0007

Montazemi, A. R., \& Qahri-Saremi, H. (2015). Factors affecting adoption of online banking: A metaanalytic structural equation modeling study. Information and Management, 52(2), 210-226. https://doi.org/10.1016/j.im.2014.11.002

Morgan, R. M., \& Hunt, S. D. (1994). The Commitment-Trust Theory of Relationship Marketing. Journal of Marketing, 58(3), 20-38. https://doi.org/10.1177/002224299405800302

Nienaber, A. M., Hofeditz, M., \& Searle, R. H. (2014). Do we bank on regulation or reputation? A meta-analysis and meta-regression of organizational trust in the financial services sector. Marketing Intelligence and Planning, 32(5), 367-407. https://doi.org/10.1108/IJBM-12-20130146

Novak, T. P., Hoffman, D. L., \& Yung, Y.-F. (2003). Measuring the Customer Experience in Online Environments: A Structural Modeling Approach. Marketing Science, 19(1), 22-42. https://doi.org/10.1287/mksc.19.1.22.15184

Orth, U. R., Bouzdine-Chameeva, T., \& Brand, K. (2013). Trust during retail encounters: A touchy proposition. Journal of Retailing, 89(3), 301-314. https://doi.org/10.1016/j.jretai.2013.02.002

Pavlou, P. A., \& Gefen, D. (2004). Building Effective Online Marketplaces with. Information Systems Research, 15(1), 37-59. https://doi.org/10.1287/isre.1040.0015

Pedersen, J. M., Matsson, P., Bergström, C. A. S., Norinder, U., Hoogstraate, J., \& Artursson, P. (2008). Prediction and identification of drug interactions with the human ATP-binding cassette 
transporter multidrug-resistance associated protein 2 (MRP2; ABCC2). In Journal of Medicinal Chemistry (Vol. 51, pp. 3275-3287). https://doi.org/10.1021/jm7015683

Rao, A. R., Qu, L., \& Ruekert, R. W. (2006). Signaling Unobservable Product Quality through a Brand Ally. Journal of Marketing Research, 36(2), 258-268. https://doi.org/10.2307/3152097

Read, A., Vance, A., Moody, G., Beckman, B., \& Lowry, P. B. (2008). Explaining and Predicting the Impact of Branding Alliances and Web Site Quality on Initial Consumer Trust of E-Commerce Web Sites. Journal of Management Information Systems, 24(4), 199-224. https://doi.org/10.2753/mis0742-1222240408

Riquelme, I. P., Román, S., Cuestas, P. J., \& Iacobucci, D. (2019). The Dark Side of Good Reputation and Loyalty in Online Retailing: When Trust Leads to Retaliation through Price Unfairness. Journal of Interactive Marketing, 47(August 2019), 35-52. https://doi.org/10.1016/j.intmar.2018.12.002

Rousseau, D. M., Sitkin, S. B., Burt, R. S., \& Camerer, C. (1998). Not so different after all: A crossdiscipline view of trust. Academy of Management Review, 23(3), 393-404. https://doi.org/10.5465/AMR.1998.926617

Selnes, F. (2002). Antecedents and consequences of trust and satisfaction in buyer-seller relationships. European Journal of Marketing, 32(3/4), 305-322. https://doi.org/10.1108/03090569810204580 Shaikh, A. A., \& Karjaluoto, H. (2014). Mobile banking adoption: A literature review. Telematics and Informatics, 32(1), 129-142. https://doi.org/10.1016/j.tele.2014.05.003

Soh, H., Reid, L. N., \& King, K. W. (2007). Trust in different advertising media. Journalism and Mass Communication Quarterly, 84(3), 455-476. https://doi.org/10.1177/107769900708400304

Soh, H., Reid, L. N., \& King, K. W. (2009). Measuring Trust In Advertising. Journal of Advertising, 38(2), 83-104. https://doi.org/10.2753/joa0091-3367380206

Spence, M. (2006). Job Market Signaling. The Quarterly Journal of Economics, 87(3), 355-374. https://doi.org/10.2307/1882010

Statista. (2019a). Consumer trust in advertising worldwide from 2007 to 2015, by ad format. Retrieved from The Statistica Portal website: https://www.statista.com/statistics/222698/consumer-trust-in-different-types-of-advertising/ 
Statista. (2019b). U.S. Digital Advertising Industry - Statistics \& Facts. Retrieved from The Statista Portal website: https://www.statista.com/topics/1176/online-advertising/

Sultan, F., Urban, G. L., Shankar, V., \& Bart, I. Y. (2005a). Determinants and Role of Trust in EBusiness: A Large Scale Empirical Study. SSRN Electronic Journal. https://doi.org/10.2139/ssrn.380404

Sultan, F., Urban, G. L., Shankar, V., \& Bart, I. Y. (2005b). Determinants and Role of Trust in EBusiness: A Large Scale Empirical Study. In SSRN Electronic Journal. https://doi.org/10.2139/ssrn.380404

Sun, Y., Wang, N., Shen, X. L., \& Zhang, J. X. (2015). Location information disclosure in locationbased social network services: Privacy calculus, benefit structure, and gender differences. Computers in Human Behavior, 52, 278-292. https://doi.org/10.1016/j.chb.2015.06.006

Telser, L. G. (2002). A Theory of Self-Enforcing Agreements. The Journal of Business, 53(1), 27-44. https://doi.org/10.1086/296069

Tuli, K. R., Mukherjee, A., \& Dekimpe, M. G. (2012). On the Value Relevance of Retailer Advertising Spending and Same-store Sales Growth. Journal of Retailing, 88(4), 447-461. https://doi.org/10.1016/j.jretai.2012.07.001

Turilli, M., Vaccaro, A., \& Taddeo, M. (2010). The Case of Online Trust. Knowledge, Technology \& Policy, 23(3-4), 333-345. https://doi.org/10.1007/s12130-010-9117-5

Venkatesh, V., \& Morris, M. G. (2000). Why Don't Men Ever Stop to Ask for Directions? Gender, Social Influence, and Their Role in Technology Acceptance and Usage Behavior. MIS Quarterly, 24(1), 115-139. https://doi.org/10.2307/3250981

Vilčeková, L. (2016). Advertising Credibility Across Different Media Channels. IJASOSInternational E-Journal of Advances in Social Sciences, 2(4), 126. https://doi.org/10.18769/ijasos.38812

Wagner, N., Hassanein, K., \& Head, M. (2010). Computer use by older adults: A multi-disciplinary review. Computers in Human Behavior, 26(5), 870-882.

https://doi.org/10.1016/j.chb.2010.03.029

Wang, C. W., Ho, R. T. H., Chan, C. L. W., \& Tse, S. (2015). Exploring personality characteristics of 
Chinese adolescents with internet-related addictive behaviors: Trait differences for gaming addiction and social networking addiction. Addictive Behaviors, 42, 32-35.

https://doi.org/10.1016/j.addbeh.2014.10.039

Wang, H., \& Hu, Z. (2009). Online trust between inexperienced consumers and experienced consumers: An empirical study. 2009 2nd International Conference on Future Information Technology and Management Engineering, FITME 2009, 167-170. https://doi.org/10.1109/FITME.2009.47

Western, B., Braga, A., Hureau, D., \& Sirois, C. (2016). Study retention as bias reduction in a hard-toreach population. Proceedings of the National Academy of Sciences, 113(20), 5477-5485. https://doi.org/10.1073/pnas.1604138113

Wong, L. W., Leong, L. Y., Hew, J. J., Tan, G. W. H., \& Ooi, K. B. (2019). Time to seize the digital evolution: Adoption of blockchain in operations and supply chain management among Malaysian SMEs. International Journal of Information Management, in-press(in-press), 1-19. https://doi.org/10.1016/j.ijinfomgt.2019.08.005

Wu, J. J., Chen, Y. H., \& Chung, Y. S. (2010). Trust factors influencing virtual community members: A study of transaction communities. Journal of Business Research, 63(9-10), 1025-1032. https://doi.org/10.1016/j.jbusres.2009.03.022

Wu, J. J., \& Tsang, A. S. L. (2008). Factors affecting members' trust belief and behaviour intention in virtual communities. Behaviour and Information Technology, 27(2), 115-125. https://doi.org/10.1080/01449290600961910

Xu, Y., Kim, H.-W., \& Koh, J. (2018). A Comparison of Online Trust Building Factors between Potential Customers and Repeat Customers. Journal of the Association for Information Systems, 5(10), 392-420. https://doi.org/10.17705/1jais.00056

Yang, K. C., Huang, C. H., Yang, C., \& Yang, S. Y. (2017). Consumer attitudes toward online video advertisement: YouTube as a platform. Kybernetes, 46(5), 840-853. https://doi.org/10.1108/K03-2016-0038

Yoon, S. J. (2002). The antecedents and consequences of trust in online-purchase decisions. Journal of Interactive Marketing, 16(2), 47-63. https://doi.org/10.1002/dir.10008 
Zaheer, A., \& Venkatraman, N. (1995). Relational governance as an interorganizational strategy: An empirical test of the role of trust in economic exchange. Strategic Management Journal, 16(5), 373-392. https://doi.org/10.1002/smj.4250160504

Zenetti, G., \& Klapper, D. (2016). Advertising Effects Under Consumer Heterogeneity - The Moderating Role of Brand Experience, Advertising Recall and Attitude. Journal of Retailing, 92(3), 352-372. https://doi.org/10.1016/j.jretai.2016.02.004

Zhou, T. (2011). An empirical examination of initial trust in mobile banking. Internet Research, 21(5), 527-540. https://doi.org/10.1007/s11277-013-1596-8

Zhou, T. (2012). Understanding users' initial trust in mobile banking: An elaboration likelihood perspective. Computers in Human Behavior, 28(4), 1518-1525. https://doi.org/10.1016/j.chb.2012.03.021

Zhou, T. (2014). An empirical examination of initial trust in mobile payment. Wireless Personal Communications, 77(2), 1519-1531. https://doi.org/10.1007/s11277-013-1596-8

Tables

Table 1

Demographic profile

\begin{tabular}{|c|c|c|c|}
\hline & & $\begin{array}{r}\text { Frequen } \\
\mathrm{cy} \\
\end{array}$ & $\begin{array}{r}\text { Perce } \\
n t\end{array}$ \\
\hline \multirow{2}{*}{ Gender } & Male & 196 & 39.2 \\
\hline & Female & 304 & 60.8 \\
\hline \multirow{4}{*}{ Marital status } & Single & 386 & 77.2 \\
\hline & Married & 108 & 21.6 \\
\hline & Divorced & 4 & 0.8 \\
\hline & Widowed & 2 & 0.4 \\
\hline \multirow{4}{*}{ Age (years) } & $20-29$ & 338 & 67.6 \\
\hline & $30-39$ & 102 & 20.4 \\
\hline & $40-49$ & 54 & 10.8 \\
\hline & 50 or more & 6 & 1.2 \\
\hline \multirow{5}{*}{ Education level } & $\begin{array}{l}\text { Secondary } \\
\text { school }\end{array}$ & 84 & 16.8 \\
\hline & $\begin{array}{l}\text { Certificate/Dipl } \\
\text { oma }\end{array}$ & 85 & 17.0 \\
\hline & Degree & 279 & 55.8 \\
\hline & Master & 49 & 9.8 \\
\hline & $\mathrm{PhD}$ & 3 & 0.6 \\
\hline \multirow{4}{*}{ Monthly income } & 1000 or less & 176 & 35.2 \\
\hline & $1001-3000$ & 191 & 38.2 \\
\hline & $3000-5000$ & 93 & 18.6 \\
\hline & 5001 or more & 40 & 8.0 \\
\hline \multirow{4}{*}{ Average hours spent in online activities daily } & $<1$ hour & 86 & 17.2 \\
\hline & $>1$ but $<3$ hours & 120 & 24.0 \\
\hline & $>3$ but $<5$ hours & 50 & 10.0 \\
\hline & $>5$ but $<7$ hours & 134 & 26.8 \\
\hline
\end{tabular}




\begin{tabular}{|c|c|c|c|}
\hline & $>7$ hours & 110 & 22.0 \\
\hline \multirow{5}{*}{$\begin{array}{l}\text { How frequent do you purchase an item after you come across an online advertisement } \\
\text { of the item? }\end{array}$} & Every time & 9 & 1.8 \\
\hline & Often & 72 & 14.4 \\
\hline & Some time & 186 & 37.2 \\
\hline & Seldom & 210 & 42.0 \\
\hline & Never & 23 & 4.6 \\
\hline \multirow{6}{*}{ On average, how much money do you spend each month for online shopping? } & 100 or less & 228 & 45.6 \\
\hline & $101-200$ & 191 & 38.2 \\
\hline & $201-300$ & 50 & 10.0 \\
\hline & $301-400$ & 19 & 3.8 \\
\hline & $401-500$ & 4 & 0.8 \\
\hline & $501-600$ & 8 & 1.6 \\
\hline \multirow{6}{*}{ How long is your experience in receiving online advertising? } & $\begin{array}{l}\text { Less than } 1 \\
\text { year }\end{array}$ & 78 & 15.6 \\
\hline & $\begin{array}{l}1 \text { but less than } 2 \\
\text { years }\end{array}$ & 71 & 14.2 \\
\hline & $\begin{array}{l}2 \text { but less than } 3 \\
\text { years }\end{array}$ & 106 & 21.2 \\
\hline & $\begin{array}{l}3 \text { but less than } 4 \\
\text { years }\end{array}$ & 117 & 23.4 \\
\hline & $\begin{array}{l}4 \text { but less than } 5 \\
\text { years }\end{array}$ & 26 & 5.2 \\
\hline & $\begin{array}{l}\text { More than } 5 \\
\text { years }\end{array}$ & 102 & 20.4 \\
\hline \multirow{5}{*}{$\begin{array}{l}\text { How often do you recommend an item to your family and friends after you come across } \\
\text { an online advertisement? }\end{array}$} & Every time & 3 & 0.6 \\
\hline & Often & 44 & 8.8 \\
\hline & Some time & 226 & 45.2 \\
\hline & Seldom & 161 & 32.2 \\
\hline & Never & 66 & 13.2 \\
\hline \multirow{5}{*}{ How often do you block an online advertisement? } & Every time & 72 & 14.4 \\
\hline & Often & 128 & 25.6 \\
\hline & Some time & 157 & 31.4 \\
\hline & Seldom & 113 & 22.6 \\
\hline & Never & 30 & 6.0 \\
\hline
\end{tabular}

Table 2

One-Sample Kolmogorov-Smirnov Test

\begin{tabular}{lcrrrrrrr}
\hline & $\mathrm{N}$ & \multicolumn{2}{c}{ Normal Parameters ${ }^{\mathrm{a}, \mathrm{b}}$} & \multicolumn{2}{c}{ Most Extreme Differences } & Kolmogorov- & $\begin{array}{r}\text { Asymp. Sig. } \\
\text { Smirnov Z }\end{array}$ & (2-tailed) \\
\cline { 3 - 6 } & & Mean & Std. Deviation & Absolute & Positive & Negative & & 0.000 \\
Reliability1 & 500 & 2.840 & 0.8967 & 0.202 & 0.202 & -0.195 & 4.507 & 0.000 \\
Reliability2 & 500 & 2.856 & 0.9701 & 0.213 & 0.213 & -0.157 & 4.767 & 0.000 \\
Reliability3 & 500 & 2.968 & 0.8766 & 0.211 & 0.211 & -0.207 & 4.728 & 0.000 \\
Reliability4 & 500 & 2.894 & 0.8765 & 0.206 & 0.190 & -0.206 & 4.609 & 0.000 \\
Reliability5 & 500 & 3.106 & 0.9102 & 0.193 & 0.190 & -0.193 & 4.316 & 0.000 \\
Reliability6 & 500 & 2.962 & 0.8330 & 0.264 & 0.264 & -0.222 & 5.899 & 0.000 \\
Reliability7 & 500 & 2.916 & 0.8476 & 0.249 & 0.249 & -0.249 & 5.578 & 0.000 \\
Reliability8 & 500 & 2.806 & 1.0269 & 0.188 & 0.188 & -0.171 & 4.198 & 0.000 \\
Reliability9 & 500 & 2.984 & 0.9621 & 0.207 & 0.207 & -0.203 & 4.624 & 0.000 \\
\hline Usefulness1 & 500 & 3.050 & 0.8203 & 0.252 & 0.242 & -0.252 & 5.628 & 0.000 \\
Usefulness2 & 500 & 3.098 & 0.8257 & 0.247 & 0.247 & -0.243 & 5.528 & 0.000 \\
Usefulness3 & 500 & 3.278 & 0.8890 & 0.226 & 0.189 & -0.226 & 5.046 & 0.000 \\
Usefulness4 & 500 & 3.204 & 1.0921 & 0.187 & 0.161 & -0.187 & 4.180 & 0.000 \\
\hline Affect1 & 500 & 3.248 & 0.8366 & 0.243 & 0.243 & -0.225 & 5.424 & 0.000
\end{tabular}




\begin{tabular}{lllllllll} 
Affect2 & 500 & 3.510 & 0.9053 & 0.268 & 0.186 & -0.268 & 5.989 & 0.000 \\
Affect3 & 500 & 3.328 & 0.9177 & 0.214 & 0.214 & -0.204 & 4.777 & 0.000 \\
\hline Willingness1 & 500 & 3.086 & 1.0142 & 0.224 & 0.160 & -0.224 & 5.014 & 0.000 \\
Willingness2 & 500 & 2.988 & 1.0069 & 0.217 & 0.193 & -0.217 & 4.842 & 0.000 \\
Willingness3 & 500 & 3.250 & 1.0534 & 0.242 & 0.158 & -0.242 & 5.406 & 0.000 \\
Willingness4 & 500 & 3.154 & 0.9779 & 0.239 & 0.151 & -0.239 & 5.334 & 0.000 \\
\hline Reputation1 & 500 & 3.782 & 0.8023 & 0.307 & 0.243 & -0.307 & 6.866 & 0.000 \\
Reputation2 & 500 & 3.832 & 0.7674 & 0.295 & 0.239 & -0.295 & 6.588 & 0.000 \\
Reputation3 & 500 & 3.528 & 0.8548 & 0.242 & 0.200 & -0.242 & 5.402 & 0.000 \\
Reputation4 & 500 & 3.898 & 0.8080 & 0.256 & 0.214 & -0.256 & 5.729 & 0.000 \\
Reputation5 & 500 & 3.812 & 0.8379 & 0.263 & 0.205 & -0.263 & 5.876 & 0.000 \\
\hline WebQuality1 & 500 & 3.330 & 0.8824 & 0.218 & 0.204 & -0.218 & 4.878 & 0.000 \\
WebQuality2 & 500 & 3.520 & 0.8432 & 0.257 & 0.189 & -0.257 & 5.756 & 0.000 \\
WebQuality3 & 500 & 3.400 & 0.8886 & 0.214 & 0.210 & -0.214 & 4.790 & 0.000 \\
WebQuality4 & 500 & 3.466 & 0.9309 & 0.279 & 0.195 & -0.279 & 6.236 & 0.000 \\
WebQuality5 & 500 & 3.454 & 0.9368 & 0.214 & 0.192 & -0.214 & 4.785 & 0.000 \\
\hline Trust1 & 500 & 2.974 & 0.8734 & 0.218 & 0.218 & -0.188 & 4.877 & 0.000 \\
Trust2 & 500 & 3.174 & 0.9041 & 0.226 & 0.170 & -0.226 & 5.043 & 0.000 \\
Trust3 & 500 & 3.284 & 0.9258 & 0.210 & 0.190 & -0.210 & 4.704 & 0.000 \\
Trust4 & 500 & 2.910 & 0.9400 & 0.230 & 0.230 & -0.210 & 5.140 & 0.000 \\
Trust5 & 500 & 2.988 & 0.9368 & 0.205 & 0.205 & -0.195 & 4.581 & 0.000 \\
\hline Gender & 500 & 1.608 & 0.4887 & 0.397 & 0.285 & -0.397 & 8.872 & 0.000 \\
\hline Age & 500 & 1.456 & 0.7329 & 0.409 & 0.409 & -0.267 & 9.148 & 0.000 \\
\hline Education & 500 & 3.604 & 0.8993 & 0.332 & 0.226 & -0.332 & 7.427 & 0.000 \\
\hline Test & & & & & & &
\end{tabular}

a. Test distribution is Normal.

b. Calculated from data.

Table 3

ANOVA test for linearity

\begin{tabular}{|c|c|c|c|c|c|c|c|}
\hline & & & Sum of Squares & $\mathrm{df}$ & Mean Square & $\mathrm{F}$ & Sig. \\
\hline \multirow{4}{*}{ Trust * Age } & \multirow{3}{*}{ Between Groups } & (Combined) & 0.578 & 3 & 0.193 & 0.315 & 0.814 \\
\hline & & Linearity & 0.132 & 1 & 0.132 & 0.216 & 0.642 \\
\hline & & Deviation from Linearity & 0.446 & 2 & 0.223 & 0.365 & 0.695 \\
\hline & Within Groups & & 303.124 & 496 & 0.611 & & \\
\hline \multirow{4}{*}{ Trust * Education } & \multirow{3}{*}{ Between Groups } & (Combined) & 4.290 & 4 & 1.073 & 1.773 & 0.133 \\
\hline & & Linearity & 0.001 & 1 & 0.001 & 0.001 & 0.973 \\
\hline & & Deviation from Linearity & 4.290 & 3 & 1.430 & 2.364 & 0.070 \\
\hline & Within Groups & & 299.412 & 495 & 0.605 & & \\
\hline \multirow{4}{*}{ Trust * Reliability } & \multirow{3}{*}{ Between Groups } & (Combined) & 215.676 & 28 & 7.703 & 41.215 & 0.000 \\
\hline & & Linearity & 170.314 & 1 & 170.314 & 911.302 & 0.000 \\
\hline & & Deviation from Linearity & 45.362 & 27 & 1.680 & 8.990 & 0.000 \\
\hline & Within Groups & & 88.026 & 471 & 0.187 & & \\
\hline Trust * Usefulness & Between Groups & (Combined) & 151.014 & 13 & 11.616 & 36.975 & 0.000 \\
\hline
\end{tabular}




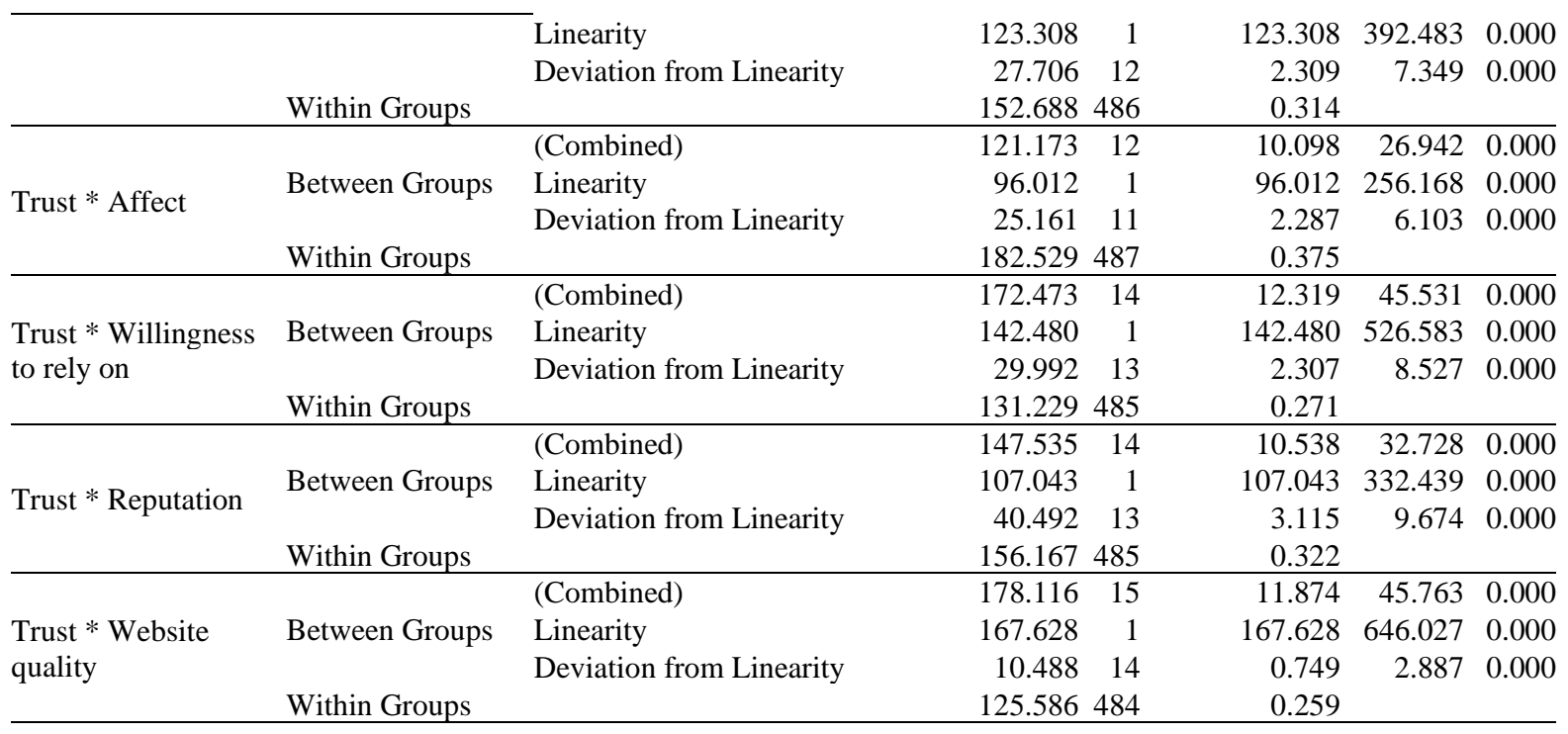

Table 4

Test for multicollinearity

\begin{tabular}{|c|c|c|c|c|c|c|c|c|}
\hline \multirow{2}{*}{\multicolumn{2}{|c|}{ Model }} & \multicolumn{2}{|c|}{$\begin{array}{l}\text { Unstandardized } \\
\text { Coefficients } \\
\end{array}$} & \multirow{2}{*}{$\begin{array}{l}\text { Standardized } \\
\text { Coefficients } \\
\text { Beta }\end{array}$} & \multirow[t]{2}{*}{$\mathrm{t}$} & \multirow[t]{2}{*}{ Sig. } & \multicolumn{2}{|c|}{$\begin{array}{l}\text { Collinearity } \\
\text { Statistics } \\
\end{array}$} \\
\hline & & B & Std. Error & & & & Tolerance & VIF \\
\hline & (Constant) & -0.039 & 0.174 & & -0.224 & 0.823 & & \\
\hline & Gender & -0.225 & 0.037 & -0.141 & -6.016 & 0.000 & 0.931 & 1.074 \\
\hline & Age & -0.013 & 0.024 & -0.012 & -0.516 & 0.606 & 0.986 & 1.015 \\
\hline & Education & 0.012 & 0.021 & 0.014 & 0.584 & 0.559 & 0.914 & 1.094 \\
\hline & Reliability & 0.444 & 0.042 & 0.418 & 10.557 & 0.000 & 0.325 & 3.072 \\
\hline \multirow[t]{6}{*}{1} & Usefulness & -0.025 & 0.044 & -0.025 & -0.566 & 0.572 & 0.268 & 3.729 \\
\hline & Affect & -0.108 & 0.039 & -0.107 & -2.751 & 0.006 & 0.337 & 2.963 \\
\hline & Willingness to rely on & 0.181 & 0.033 & 0.212 & 5.434 & 0.000 & 0.335 & 2.982 \\
\hline & Reputation & 0.195 & 0.038 & 0.160 & 5.195 & 0.000 & 0.538 & 1.860 \\
\hline & Website quality & 0.379 & 0.040 & 0.325 & 9.407 & 0.000 & 0.428 & 2.336 \\
\hline & Hours spent & -0.006 & 0.014 & -0.010 & -0.405 & 0.686 & 0.767 & 1.304 \\
\hline
\end{tabular}

Note: Dependent Variable: Trust in online advertising

Table 5

Harman's single factor

\begin{tabular}{|c|c|c|c|c|c|c|}
\hline \multirow[t]{2}{*}{ Component } & \multicolumn{3}{|c|}{ Initial Eigenvalues } & \multicolumn{3}{|c|}{ Extraction Sums of Squared Loadings } \\
\hline & Total & $\%$ of Variance & Cumulative $\%$ & Total & $\%$ of Variance & Cumulative \% \\
\hline 1 & 17.340 & 48.166 & 48.166 & 17.340 & 48.166 & 48.166 \\
\hline 2 & 2.841 & 7.893 & 56.059 & & & \\
\hline 3 & 1.937 & 5.380 & 61.439 & & & \\
\hline 4 & 1.377 & 3.826 & 65.264 & & & \\
\hline 5 & 1.314 & 3.651 & 68.915 & & & \\
\hline 6 & 1.217 & 3.381 & 72.295 & & & \\
\hline 7 & 1.091 & 3.031 & 75.326 & & & \\
\hline 8 & 0.967 & 2.687 & 78.014 & & & \\
\hline 9 & 0.931 & 2.586 & 80.599 & & & \\
\hline 10 & 0.753 & 2.092 & 82.691 & & & \\
\hline 11 & 0.717 & 1.991 & 84.682 & & & \\
\hline 12 & 0.548 & 1.521 & 86.203 & & & \\
\hline 13 & 0.502 & 1.395 & 87.598 & & & \\
\hline 14 & 0.450 & 1.251 & 88.849 & & & \\
\hline 15 & 0.442 & 1.228 & 90.078 & & & \\
\hline
\end{tabular}




\begin{tabular}{lrrr}
16 & 0.405 & 1.125 & 91.202 \\
17 & 0.365 & 1.013 & 92.216 \\
18 & 0.337 & 0.936 & 93.152 \\
19 & 0.300 & 0.834 & 93.985 \\
20 & 0.258 & 0.716 & 94.701 \\
21 & 0.235 & 0.652 & 95.353 \\
22 & 0.212 & 0.589 & 95.942 \\
23 & 0.190 & 0.528 & 96.469 \\
24 & 0.172 & 0.479 & 96.948 \\
25 & 0.163 & 0.453 & 97.401 \\
26 & 0.147 & 0.409 & 97.811 \\
27 & 0.143 & 0.398 & 98.208 \\
28 & 0.124 & 0.344 & 98.552 \\
29 & 0.107 & 0.298 & 98.850 \\
30 & 0.096 & 0.267 & 99.117 \\
31 & 0.088 & 0.243 & 99.361 \\
32 & 0.081 & 0.224 & 99.584 \\
33 & 0.055 & 0.153 & 99.737 \\
34 & 0.052 & 0.143 & 99.880 \\
35 & 0.043 & 0.120 & 100.000 \\
36 & $1.004 \mathrm{E}-013$ & $1.012 \mathrm{E}-013$ & 100.000 \\
\hline $\mathrm{Ex}$ & 0.013 & \\
\hline
\end{tabular}

Extraction Method: Principal Component Analysis.

Table 6

Independent Samples Test

\begin{tabular}{|c|c|c|c|c|c|c|c|c|c|c|}
\hline & & \multicolumn{2}{|c|}{$\begin{array}{l}\text { Levene's Test } \\
\text { for Equality of } \\
\text { Variances }\end{array}$} & \multicolumn{7}{|c|}{ t-test for Equality of Means } \\
\hline & & \multirow[t]{2}{*}{ F } & \multirow[t]{2}{*}{ Sig. } & \multirow[t]{2}{*}{$\mathrm{t}$} & \multirow[t]{2}{*}{$\mathrm{df}$} & \multirow[t]{2}{*}{$\begin{array}{l}\text { Sig. } \\
(2- \\
\text { tailed) }\end{array}$} & \multirow[t]{2}{*}{$\begin{array}{l}\text { Mean } \\
\text { Difference }\end{array}$} & \multirow[t]{2}{*}{$\begin{array}{l}\text { Std. Error } \\
\text { Difference }\end{array}$} & \multicolumn{2}{|c|}{$\begin{array}{l}\text { 95\% Confidence } \\
\text { Interval of the } \\
\text { Difference }\end{array}$} \\
\hline & & & & & & & & & Lower & Upper \\
\hline \multirow[t]{2}{*}{ Reliability } & Equal variances assumed & 0.083 & 0.773 & -0.458 & 249.000 & 0.647 & -0.042 & 0.092 & -0.224 & 0.139 \\
\hline & Equal variances not assumed & & & -0.458 & 248.987 & 0.647 & -0.042 & 0.092 & -0.224 & 0.139 \\
\hline \multirow[t]{2}{*}{ Usefulness } & Equal variances assumed & 0.022 & 0.884 & -0.401 & 249.000 & 0.689 & -0.039 & 0.096 & -0.228 & 0.151 \\
\hline & Equal variances not assumed & & & -0.401 & 248.687 & 0.689 & -0.039 & 0.096 & -0.228 & 0.151 \\
\hline \multirow[t]{2}{*}{ Affect } & Equal variances assumed & 0.037 & 0.848 & -0.243 & 249.000 & 0.808 & -0.024 & 0.098 & -0.216 & 0.168 \\
\hline & Equal variances not assumed & & & -0.243 & 248.962 & 0.808 & -0.024 & 0.098 & -0.216 & 0.168 \\
\hline \multirow{2}{*}{ Willingness } & Equal variances assumed & 0.015 & 0.902 & -0.387 & 249.000 & 0.699 & -0.045 & 0.116 & -0.273 & 0.183 \\
\hline & Equal variances not assumed & & & -0.387 & 248.832 & 0.699 & -0.045 & 0.116 & -0.273 & 0.183 \\
\hline \multirow{2}{*}{ Reputation } & Equal variances assumed & 0.003 & 0.960 & -0.237 & 249.000 & 0.813 & -0.019 & 0.082 & -0.180 & 0.142 \\
\hline & Equal variances not assumed & & & -0.237 & 248.967 & 0.813 & -0.019 & 0.082 & -0.180 & 0.142 \\
\hline \multirow{2}{*}{$\begin{array}{l}\text { Website } \\
\text { Quality }\end{array}$} & Equal variances assumed & 0.005 & 0.941 & -0.167 & 249.000 & 0.867 & -0.014 & 0.084 & -0.180 & 0.151 \\
\hline & Equal variances not assumed & & & -0.167 & 248.990 & 0.867 & -0.014 & 0.084 & -0.180 & 0.151 \\
\hline \multirow[t]{2}{*}{ Trust } & Equal variances assumed & 0.154 & 0.695 & -0.222 & 249.000 & 0.825 & -0.022 & 0.098 & -0.215 & 0.172 \\
\hline & Equal variances not assumed & & & -0.222 & 248.957 & 0.825 & -0.022 & 0.098 & -0.215 & 0.172 \\
\hline
\end{tabular}


Table 7

Construct reliability and convergent validity

\begin{tabular}{lllll}
\hline & Cronbach's Alpha & rho_A & Composite Reliability & Average Variance Extracted (AVE) \\
\hline Affective & 0.842 & 0.855 & 0.904 & 0.759 \\
Reliability & 0.933 & 0.936 & 0.944 & 0.651 \\
Reputation & 0.845 & 0.858 & 0.889 & 0.618 \\
Trust & 0.905 & 0.908 & 0.929 & 0.725 \\
Usefulness & 0.871 & 0.881 & 0.912 & 0.722 \\
Website quality & 0.824 & 0.833 & 0.884 & 0.655 \\
Willingness to rely on & 0.925 & 0.925 & 0.947 & 0.816 \\
\hline
\end{tabular}

Table 8

Fornell-Larcker's criterion

\begin{tabular}{llllllll}
\hline & Affective & Reliability & Reputation & Trust & Usefulness & Website quality & Willingness to rely on \\
\hline Affective & $\mathbf{0 . 8 7 1}$ & & & & & & \\
Reliability & 0.675 & $\mathbf{0 . 8 0 7}$ & & & & & \\
Reputation & 0.479 & 0.425 & $\mathbf{0 . 7 8 6}$ & & & & \\
Trust & 0.573 & 0.758 & 0.606 & $\mathbf{0 . 8 5 1}$ & & & \\
Usefulness & 0.754 & 0.781 & 0.450 & 0.643 & $\mathbf{0 . 8 5 0}$ & & \\
Website quality & 0.626 & 0.635 & 0.605 & 0.758 & 0.565 & $\mathbf{0 . 8 1 0}$ & $\mathbf{0 . 9 0 3}$ \\
Willingness to rely on & 0.682 & 0.687 & 0.551 & 0.687 & 0.741 & 0.616 & \\
\hline
\end{tabular}

Note: Diagonal element represents square root of AVE; Trust = Trust in online advertising.

Table 9

HTMT ratio

\begin{tabular}{llllllll}
\hline & Affective & Reliability & Reputation & Trust & Usefulness & Website quality & Willingness to rely on \\
\hline Affective & & & & & & & \\
Reliability & 0.762 & & & & & & \\
Reputation & 0.551 & 0.462 & & & & & \\
Trust & 0.648 & 0.817 & 0.681 & & & \\
Usefulness & 0.872 & 0.863 & 0.492 & 0.718 & & \\
Website quality & 0.743 & 0.724 & 0.719 & 0.867 & 0.668 & \\
Willingness to rely on & 0.769 & 0.737 & 0.610 & 0.750 & 0.822 & 0.711 \\
\hline
\end{tabular}

Note: Trust $=$ Trust in online advertising.

Table 10

Predictive power

\begin{tabular}{lrr}
\hline & R Square & R Square Adjusted \\
\hline Trust in online advertising & 0.751 & 0.746 \\
\hline
\end{tabular}

Table 11

Path analysis

\begin{tabular}{lllll}
\hline & $\beta$ coefficient & T Statistics & P Values & Remark \\
\hline Affective $\rightarrow$ Trust & -0.138 & 3.853 & 0.000 & Supported \\
Age $\rightarrow$ Trust & 0.010 & 0.383 & 0.701 & Not supported \\
Education $\rightarrow$ Trust & 0.022 & 0.871 & 0.384 & Not supported \\
Gender $\rightarrow$ Trust & -0.039 & 1.544 & 0.123 & Not supported \\
Hours spent $\rightarrow$ Trust & 0.082 & 3.259 & 0.001 & Supported \\
Reliability $\rightarrow$ Trust & 0.438 & 11.050 & 0.000 & Supported \\
Reputation $\rightarrow$ Trust & 0.178 & 6.706 & 0.000 & Supported \\
Usefulness $\rightarrow$ Trust & -0.001 & 0.019 & 0.984 & Not supported \\
Website quality $\rightarrow$ Trust & 0.366 & 9.751 & 0.000 & Supported \\
Willingness to rely on $\rightarrow$ Trust & 0.144 & 3.536 & 0.000 & Supported \\
\hline
\end{tabular}


Table 12

RMSE values

\begin{tabular}{llllll}
\hline Training & & & Testing & \\
\hline $\mathrm{N}$ & SSE & RMSE & $\mathrm{N}$ & SSE & RMSE \\
\hline 446 & 4.348 & 0.0987 & 54 & 0.406 & 0.0867 \\
448 & 2.343 & 0.0723 & 52 & 0.255 & 0.0700 \\
451 & 2.314 & 0.0716 & 49 & 0.322 & 0.0811 \\
452 & 2.724 & 0.0776 & 48 & 0.222 & 0.0680 \\
448 & 2.424 & 0.0736 & 52 & 0.265 & 0.0714 \\
452 & 4.179 & 0.0962 & 48 & 0.499 & 0.1020 \\
448 & 4.409 & 0.0992 & 52 & 0.657 & 0.1124 \\
458 & 2.350 & 0.0716 & 42 & 0.222 & 0.0727 \\
451 & 2.652 & 0.0767 & 49 & 0.271 & 0.0744 \\
451 & 2.416 & 0.0732 & 49 & 0.309 & 0.0794 \\
\hline Mean & 3.016 & 0.0811 & Mean & 0.343 & 0.0818 \\
\hline Standard deviation & 0.9058 & 0.0119 & Standard deviation & 0.1402 & 0.0147 \\
\hline
\end{tabular}

Note: SSE $=$ Sum square errors, RMSE $=$ Root mean square errors, $\mathrm{N}=$ sample size

Table 13

Sensitivity analysis

\begin{tabular}{llllll}
\hline $\mathrm{AF}$ & $\mathrm{HR}$ & RL & RP & WQ & WL \\
\hline 0.117 & 0.018 & 0.357 & 0.196 & 0.170 & 0.142 \\
0.141 & 0.053 & 0.335 & 0.151 & 0.171 & 0.150 \\
0.059 & 0.073 & 0.357 & 0.113 & 0.204 & 0.194 \\
0.113 & 0.086 & 0.222 & 0.144 & 0.257 & 0.178 \\
0.084 & 0.078 & 0.323 & 0.121 & 0.194 & 0.199 \\
0.111 & 0.016 & 0.409 & 0.130 & 0.263 & 0.071 \\
0.150 & 0.009 & 0.348 & 0.128 & 0.227 & 0.138 \\
0.153 & 0.055 & 0.354 & 0.129 & 0.179 & 0.130 \\
0.099 & 0.102 & 0.199 & 0.115 & 0.289 & 0.197 \\
0.120 & 0.073 & 0.325 & 0.148 & 0.199 & 0.135 \\
\hline 0.115 & 0.056 & 0.323 & 0.138 & 0.215 & 0.153 \\
\hline 35.522 & 17.436 & 100.000 & 42.583 & 66.677 & 47.507 \\
\hline
\end{tabular}

Note: Dependent variable $=$ Trust in online advertising

Appendix A

Survey instrument

\begin{tabular}{|c|c|}
\hline $\mathrm{RL}$ & Reliability \\
\hline \multicolumn{2}{|r|}{ Information conveyed in online advertising is } \\
\hline RL1 & Honest \\
\hline RL2 & Truthful \\
\hline RL3 & Credible \\
\hline RL4 & Reliable \\
\hline RL5 & Dependable \\
\hline RL6 & Accurate \\
\hline RL7 & Factual \\
\hline RL8 & Complete \\
\hline RL9 & Clear \\
\hline US & Usefulness \\
\hline \multicolumn{2}{|r|}{ Information conveyed in online advertising is } \\
\hline US1 & Valuable \\
\hline
\end{tabular}




\begin{tabular}{|c|l|}
\hline US2 & Good \\
\hline US3 & Useful \\
\hline US4 & Helps people make the best decisions \\
\hline AF & Affect \\
\hline \multicolumn{2}{|c|}{ Information conveyed in online advertising is ... } \\
\hline AF1 & Likable \\
\hline AF2 & Enjoyable \\
\hline AF3 & Positive \\
\hline WR & Willingness to Rely On \\
\hline WR1 & I am willing to rely on ad-conveyed information when making purchase-related decisions. \\
\hline WR2 & $\begin{array}{l}\text { I am willing to make important purchase-related decision based on ad-conveyed } \\
\text { information. }\end{array}$ \\
\hline WR3 & $\begin{array}{l}\text { I am willing to consider the ad-conveyed information when making purchase-related } \\
\text { decisions. }\end{array}$ \\
\hline WR4 & $\begin{array}{l}\text { I am willing to recommend the product or service that I have seen in ads to my friends or } \\
\text { family }\end{array}$ \\
\hline RP & Reputation \\
\hline RP1 & I believe in online advertising of companies that are well known \\
\hline RP2 & I believe in online advertising of companies that are concerned about their customers \\
\hline RP3 & I believe in online advertising of companies that I recommend to my friend and relative \\
\hline RP4 & I believe in online advertising of companies that are good reputation in the market \\
\hline RP5 & I believe in online advertising of companies that I am satisfied with my overall experience \\
\hline WQ & Website Quality \\
\hline WQ1 & The website of displayed online advertising is reliable. \\
\hline WQ2 & The navigation of website that displayed online advertising is effective \\
\hline WQ3 & The layout of website that displayed online advertising is clear \\
\hline WQ4 & The loading of website that displayed online advertising is quick. \\
\hline WQ5 & The website of displayed online advertising meets a variety of needs. \\
\hline TR & Customer's Trust in Online Advertising \\
\hline TR1 & I believe online advertising is trustworthy \\
\hline TR2 & $\begin{array}{l}\text { I would feel comfortable depending on the information provided by online advertising } \\
\text { when making purchasing decision }\end{array}$ \\
\hline TR3 & I can rely on online advertising information in making purchasing decision \\
\hline TR4 & I believe that online advertising is believable \\
\hline TR5 & I trust online advertising \\
\hline
\end{tabular}

Appendix B

Substantive and method variance

\begin{tabular}{|c|c|c|c|c|c|c|c|c|c|}
\hline Path & $\begin{array}{l}\text { Substantive } \\
\text { loading }\end{array}$ & $\begin{array}{l}\text { Substantive } \\
\text { variance }\end{array}$ & $\begin{array}{l}\mathrm{T} \\
\text { Statistic } \\
\mathrm{S}\end{array}$ & $\begin{array}{l}\mathrm{P} \\
\text { Value } \\
\mathrm{S}\end{array}$ & Path & $\begin{array}{l}\text { Method } \\
\text { loading }\end{array}$ & $\begin{array}{l}\text { Method } \\
\text { variance }\end{array}$ & $\begin{array}{l}\mathrm{T} \\
\text { Statistic } \\
\mathrm{S}\end{array}$ & $\begin{array}{l}\mathrm{P} \\
\text { Value } \\
\mathrm{S}\end{array}$ \\
\hline $\begin{array}{l}\mathrm{AF} \rightarrow \\
\mathrm{AF} 1\end{array}$ & 0.710 & 0.504 & 17.722 & 0.000 & $\begin{array}{l}\text { Method } \rightarrow \\
\text { AF1 }\end{array}$ & 0.183 & 0.034 & 4.297 & 0.000 \\
\hline $\begin{array}{l}\mathrm{AF} \rightarrow \\
\mathrm{AF} 2\end{array}$ & 0.972 & 0.944 & 33.800 & 0.000 & $\begin{array}{l}\text { Method } \rightarrow \\
\text { AF2 }\end{array}$ & -0.096 & 0.009 & 2.789 & 0.005 \\
\hline $\begin{array}{l}\mathrm{AF} \rightarrow \\
\mathrm{AF} 3\end{array}$ & 0.933 & 0.870 & 25.929 & 0.000 & $\begin{array}{l}\text { Method } \rightarrow \\
\text { AF3 }\end{array}$ & -0.087 & 0.007 & 2.517 & 0.012 \\
\hline $\begin{array}{l}\mathrm{RL} \rightarrow \\
\mathrm{RL} 1\end{array}$ & 0.705 & 0.497 & 13.508 & 0.000 & $\begin{array}{l}\text { Method } \rightarrow \\
\text { RL1 }\end{array}$ & 0.158 & 0.025 & 2.818 & 0.005 \\
\hline
\end{tabular}




\begin{tabular}{|c|c|c|c|c|c|c|c|c|c|}
\hline $\begin{array}{l}\mathrm{RL} \rightarrow \\
\mathrm{RL} 2\end{array}$ & 0.864 & 0.747 & 18.453 & 0.000 & $\begin{array}{l}\text { Method } \rightarrow \\
\text { RL2 }\end{array}$ & 0.026 & 0.001 & 0.488 & 0.626 \\
\hline $\begin{array}{l}\mathrm{RL} \rightarrow \\
\mathrm{RL} 3\end{array}$ & 0.885 & 0.783 & 15.967 & 0.000 & $\begin{array}{l}\text { Method } \rightarrow \\
\text { RL3 }\end{array}$ & -0.099 & 0.010 & 1.660 & 0.097 \\
\hline $\begin{array}{l}\mathrm{RL} \rightarrow \\
\mathrm{RL} 4\end{array}$ & 0.925 & 0.856 & 21.282 & 0.000 & $\begin{array}{l}\text { Method } \rightarrow \\
\text { RL4 }\end{array}$ & -0.088 & 0.008 & 1.879 & 0.060 \\
\hline $\begin{array}{l}\mathrm{RL} \rightarrow \\
\mathrm{RL} 5\end{array}$ & 0.652 & 0.425 & 8.535 & 0.000 & $\begin{array}{l}\text { Method } \rightarrow \\
\text { RL5 }\end{array}$ & 0.115 & 0.013 & 1.529 & 0.127 \\
\hline $\begin{array}{l}\mathrm{RL} \rightarrow \\
\mathrm{RL6}\end{array}$ & 0.932 & 0.869 & 18.504 & 0.000 & $\begin{array}{l}\text { Method } \rightarrow \\
\text { RL6 }\end{array}$ & -0.170 & 0.029 & 3.093 & 0.002 \\
\hline $\begin{array}{l}\mathrm{RL} \rightarrow \\
\mathrm{RL7}\end{array}$ & 0.694 & 0.482 & 9.871 & 0.000 & $\begin{array}{l}\text { Method } \rightarrow \\
\text { RL7 }\end{array}$ & 0.109 & 0.012 & 1.653 & 0.099 \\
\hline $\begin{array}{l}\mathrm{RL} \rightarrow \\
\mathrm{RL8}\end{array}$ & 0.933 & 0.870 & 15.728 & 0.000 & $\begin{array}{l}\text { Method } \rightarrow \\
\text { RL8 }\end{array}$ & -0.165 & 0.027 & 2.615 & 0.009 \\
\hline $\begin{array}{l}\text { RL } \rightarrow \\
\text { RL9 }\end{array}$ & 0.668 & 0.446 & 9.231 & 0.000 & $\begin{array}{l}\text { Method } \rightarrow \\
\text { RL9 }\end{array}$ & 0.107 & 0.012 & 1.469 & 0.142 \\
\hline $\begin{array}{l}\mathrm{RP} \rightarrow \\
\mathrm{RP} 1\end{array}$ & 0.670 & 0.449 & 16.593 & 0.000 & $\begin{array}{l}\text { Method } \rightarrow \\
\text { RP1 }\end{array}$ & 0.189 & 0.036 & 4.194 & 0.000 \\
\hline $\begin{array}{l}\mathrm{RP} \rightarrow \\
\mathrm{RP} 2\end{array}$ & 0.698 & 0.487 & 18.570 & 0.000 & $\begin{array}{l}\text { Method } \rightarrow \\
\text { RP2 }\end{array}$ & 0.148 & 0.022 & 3.313 & 0.001 \\
\hline $\begin{array}{l}\mathrm{RP} \rightarrow \\
\mathrm{RP} 3\end{array}$ & 0.771 & 0.595 & 22.187 & 0.000 & $\begin{array}{l}\text { Method } \rightarrow \\
\text { RP3 }\end{array}$ & 0.017 & 0.000 & 0.388 & 0.698 \\
\hline $\begin{array}{l}\mathrm{RP} \rightarrow \\
\mathrm{RP} 4\end{array}$ & 0.961 & 0.924 & 48.332 & 0.000 & $\begin{array}{l}\text { Method } \rightarrow \\
\text { RP4 }\end{array}$ & -0.181 & 0.033 & 6.005 & 0.000 \\
\hline $\begin{array}{l}\mathrm{RP} \rightarrow \\
\mathrm{RP5}\end{array}$ & 0.838 & 0.703 & 22.684 & 0.000 & $\begin{array}{l}\text { Method } \rightarrow \\
\text { RP5 }\end{array}$ & -0.187 & 0.035 & 4.917 & 0.000 \\
\hline $\begin{array}{l}\text { Trust } \rightarrow \\
\text { TR1 }\end{array}$ & 0.604 & 0.365 & 9.655 & 0.000 & $\begin{array}{l}\text { Method } \rightarrow \\
\text { TR1 }\end{array}$ & 0.249 & 0.062 & 3.610 & 0.000 \\
\hline $\begin{array}{l}\text { Trust } \rightarrow \\
\text { TR2 }\end{array}$ & 0.864 & 0.747 & 14.565 & 0.000 & $\begin{array}{l}\text { Method } \rightarrow \\
\text { TR2 }\end{array}$ & -0.064 & 0.004 & 0.900 & 0.368 \\
\hline $\begin{array}{l}\text { Trust } \rightarrow \\
\text { TR3 }\end{array}$ & 1.046 & 1.093 & 26.184 & 0.000 & $\begin{array}{l}\text { Method } \rightarrow \\
\text { TR3 }\end{array}$ & -0.203 & 0.041 & 4.261 & 0.000 \\
\hline $\begin{array}{l}\text { Trust } \rightarrow \\
\text { TR4 }\end{array}$ & 0.950 & 0.903 & 23.703 & 0.000 & $\begin{array}{l}\text { Method } \rightarrow \\
\text { TR4 }\end{array}$ & -0.084 & 0.007 & 1.789 & 0.074 \\
\hline $\begin{array}{l}\text { Trust } \rightarrow \\
\text { TR5 }\end{array}$ & 0.789 & 0.623 & 18.710 & 0.000 & $\begin{array}{l}\text { Method } \rightarrow \\
\text { TR5 }\end{array}$ & 0.104 & 0.011 & 2.513 & 0.012 \\
\hline $\begin{array}{l}\mathrm{US} \rightarrow \\
\mathrm{US} 1\end{array}$ & 1.042 & 1.085 & 24.353 & 0.000 & $\begin{array}{l}\text { Method } \rightarrow \\
\text { US1 }\end{array}$ & -0.220 & 0.049 & 3.980 & 0.000 \\
\hline $\begin{array}{l}\mathrm{US} \rightarrow \\
\mathrm{US} 2\end{array}$ & 0.720 & 0.518 & 23.336 & 0.000 & $\begin{array}{l}\text { Method } \rightarrow \\
\text { US2 }\end{array}$ & 0.202 & 0.041 & 6.118 & 0.000 \\
\hline $\begin{array}{l}\mathrm{US} \rightarrow \\
\mathrm{US} 3\end{array}$ & 0.931 & 0.868 & 27.597 & 0.000 & $\begin{array}{l}\text { Method } \rightarrow \\
\text { US3 }\end{array}$ & -0.079 & 0.006 & 2.070 & 0.039 \\
\hline $\begin{array}{l}\mathrm{US} \rightarrow \\
\mathrm{US} 4\end{array}$ & 0.710 & 0.504 & 13.315 & 0.000 & $\begin{array}{l}\text { Method } \rightarrow \\
\text { US4 }\end{array}$ & 0.091 & 0.008 & 1.527 & 0.127 \\
\hline $\begin{array}{l}\text { WQ } \rightarrow \\
\text { WQ1 }\end{array}$ & 0.607 & 0.368 & 10.652 & 0.000 & $\begin{array}{l}\text { Method } \rightarrow \\
\text { WQ1 }\end{array}$ & 0.146 & 0.021 & 2.209 & 0.027 \\
\hline $\begin{array}{l}\text { WQ } \rightarrow \\
\text { WQ2 }\end{array}$ & 0.852 & 0.725 & 27.765 & 0.000 & $\begin{array}{l}\text { Method } \rightarrow \\
\text { WQ2 }\end{array}$ & 0.017 & 0.000 & 0.423 & 0.672 \\
\hline $\begin{array}{l}\text { WQ } \rightarrow \\
\text { WQ3 }\end{array}$ & 0.652 & 0.425 & 13.450 & 0.000 & $\begin{array}{l}\text { Method } \rightarrow \\
\text { WQ3 }\end{array}$ & 0.130 & 0.017 & 2.667 & 0.008 \\
\hline $\begin{array}{l}\text { WQ } \rightarrow \\
\text { WQ4 }\end{array}$ & 0.847 & 0.717 & 15.097 & 0.000 & $\begin{array}{l}\text { Method } \rightarrow \\
\text { WQ4 }\end{array}$ & -0.304 & 0.093 & 3.258 & 0.001 \\
\hline $\begin{array}{l}\text { WQ } \rightarrow \\
\text { WQ5 }\end{array}$ & 0.784 & 0.615 & 18.500 & 0.000 & $\begin{array}{l}\text { Method } \rightarrow \\
\text { WQ5 }\end{array}$ & 0.011 & 0.000 & 0.228 & 0.819 \\
\hline $\begin{array}{l}\mathrm{WR} \rightarrow \\
\mathrm{WR} 1\end{array}$ & 0.922 & 0.850 & 38.032 & 0.000 & $\begin{array}{l}\text { Method } \rightarrow \\
\text { WR1 }\end{array}$ & -0.009 & 0.000 & 0.351 & 0.726 \\
\hline $\begin{array}{l}\text { WR } \rightarrow \\
\text { WR2 }\end{array}$ & 1.083 & 1.173 & 41.983 & 0.000 & $\begin{array}{l}\text { Method } \rightarrow \\
\text { WR2 }\end{array}$ & -0.196 & 0.038 & 6.551 & 0.000 \\
\hline $\begin{array}{l}\mathrm{WR} \rightarrow \\
\mathrm{WR} 3\end{array}$ & 0.879 & 0.772 & 28.239 & 0.000 & $\begin{array}{l}\text { Method } \rightarrow \\
\text { WR3 }\end{array}$ & 0.030 & 0.001 & 0.893 & 0.372 \\
\hline \multirow[t]{2}{*}{$\begin{array}{l}\mathrm{WR} \rightarrow \\
\mathrm{WR} 4\end{array}$} & 0.724 & 0.525 & 20.979 & 0.000 & $\begin{array}{l}\text { Method } \rightarrow \\
\text { WR4 }\end{array}$ & 0.181 & 0.128 & 4.781 & 0.000 \\
\hline & mean & 0.695 & & & & mean & 0.024 & & \\
\hline
\end{tabular}

Note: $\mathrm{AF}=$ Affective, $\mathrm{RL}=$ Reliability, $\mathrm{RP}=$ Reputation, $\mathrm{US}=$ Usefulness, $\mathrm{WQ}=$ Website quality, $\mathrm{WR}=$ Willingness to rely on, $\mathrm{TR}=$ Trust in online advertising.

\section{Appendix C}

Cross-loadings 


\begin{tabular}{|c|c|c|c|c|c|c|c|c|c|c|c|}
\hline & $\mathrm{AF}$ & $\mathrm{AG}$ & EDU & GDR & HR & $\mathrm{RL}$ & $\mathrm{RP}$ & Trust & US & WQ & WR \\
\hline A1 & 0.876 & -0.005 & -0.053 & 0.029 & 0.188 & 0.631 & 0.474 & 0.557 & 0.713 & 0.604 & 0.613 \\
\hline A2 & 0.892 & 0.011 & -0.030 & 0.064 & 0.106 & 0.535 & 0.410 & 0.501 & 0.646 & 0.503 & 0.615 \\
\hline A3 & 0.844 & -0.035 & -0.071 & 0.041 & 0.042 & 0.597 & 0.354 & 0.425 & 0.599 & 0.520 & 0.548 \\
\hline $\mathrm{R} 1$ & 0.532 & 0.005 & -0.143 & 0.021 & 0.269 & 0.853 & 0.375 & 0.708 & 0.687 & 0.568 & 0.660 \\
\hline R2 & 0.602 & 0.011 & -0.107 & 0.033 & 0.233 & 0.891 & 0.343 & 0.694 & 0.683 & 0.573 & 0.637 \\
\hline R3 & 0.529 & 0.029 & -0.113 & 0.053 & 0.180 & 0.790 & 0.393 & 0.542 & 0.597 & 0.458 & 0.526 \\
\hline R4 & 0.551 & -0.040 & -0.028 & 0.067 & 0.113 & 0.844 & 0.364 & 0.608 & 0.717 & 0.549 & 0.476 \\
\hline R5 & 0.552 & 0.006 & -0.056 & 0.112 & 0.229 & 0.752 & 0.330 & 0.567 & 0.665 & 0.436 & 0.561 \\
\hline R6 & 0.484 & 0.042 & -0.009 & 0.125 & 0.137 & 0.783 & 0.298 & 0.619 & 0.519 & 0.510 & 0.412 \\
\hline R7 & 0.601 & 0.052 & -0.102 & 0.116 & 0.076 & 0.793 & 0.448 & 0.606 & 0.556 & 0.503 & 0.591 \\
\hline $\mathrm{R} 8$ & 0.473 & 0.014 & -0.083 & 0.069 & 0.157 & 0.782 & 0.201 & 0.559 & 0.598 & 0.476 & 0.564 \\
\hline R9 & 0.580 & -0.032 & -0.056 & 0.066 & 0.047 & 0.763 & 0.330 & 0.567 & 0.647 & 0.516 & 0.545 \\
\hline REP1 & 0.442 & -0.004 & 0.016 & 0.040 & 0.049 & 0.450 & 0.814 & 0.557 & 0.490 & 0.489 & 0.525 \\
\hline REP2 & 0.510 & -0.013 & 0.081 & -0.052 & -0.027 & 0.359 & 0.803 & 0.512 & 0.466 & 0.606 & 0.538 \\
\hline REP3 & 0.428 & 0.005 & 0.077 & 0.033 & 0.017 & 0.351 & 0.776 & 0.459 & 0.399 & 0.392 & 0.405 \\
\hline REP4 & 0.176 & 0.041 & 0.066 & 0.018 & -0.020 & 0.283 & 0.840 & 0.472 & 0.215 & 0.454 & 0.331 \\
\hline REP5 & 0.294 & 0.029 & 0.010 & 0.010 & -0.087 & 0.171 & 0.689 & 0.344 & 0.111 & 0.421 & 0.324 \\
\hline $\mathrm{T} 1$ & 0.526 & 0.025 & -0.041 & 0.015 & 0.168 & 0.727 & 0.476 & 0.831 & 0.569 & 0.687 & 0.608 \\
\hline $\mathrm{T} 2$ & 0.461 & -0.038 & 0.023 & 0.008 & 0.169 & 0.524 & 0.581 & 0.801 & 0.511 & 0.567 & 0.585 \\
\hline T3 & 0.441 & 0.024 & -0.036 & -0.017 & 0.233 & 0.623 & 0.504 & 0.865 & 0.469 & 0.627 & 0.539 \\
\hline $\mathrm{T} 4$ & 0.495 & 0.025 & 0.043 & 0.040 & 0.160 & 0.663 & 0.420 & 0.873 & 0.592 & 0.609 & 0.585 \\
\hline $\mathrm{T} 5$ & 0.511 & 0.052 & 0.001 & 0.070 & 0.208 & 0.671 & 0.599 & 0.884 & 0.590 & 0.718 & 0.605 \\
\hline U1 & 0.587 & -0.018 & -0.041 & 0.036 & 0.101 & 0.618 & 0.330 & 0.487 & 0.843 & 0.382 & 0.593 \\
\hline U2 & 0.683 & -0.008 & -0.064 & 0.051 & 0.147 & 0.746 & 0.465 & 0.629 & 0.900 & 0.581 & 0.701 \\
\hline $\mathrm{U} 3$ & 0.686 & -0.017 & -0.007 & 0.053 & 0.009 & 0.648 & 0.433 & 0.536 & 0.859 & 0.437 & 0.560 \\
\hline U4 & 0.599 & -0.009 & -0.052 & 0.043 & 0.193 & 0.630 & 0.283 & 0.518 & 0.795 & 0.500 & 0.656 \\
\hline W1 & 0.601 & 0.052 & -0.083 & 0.060 & 0.199 & 0.655 & 0.443 & 0.631 & 0.686 & 0.540 & 0.914 \\
\hline W2 & 0.549 & 0.062 & -0.076 & 0.048 & 0.277 & 0.596 & 0.423 & 0.599 & 0.599 & 0.513 & 0.914 \\
\hline W3 & 0.637 & 0.013 & -0.003 & 0.014 & 0.129 & 0.592 & 0.546 & 0.620 & 0.699 & 0.569 & 0.904 \\
\hline W4 & 0.676 & 0.022 & -0.085 & 0.044 & 0.178 & 0.637 & 0.576 & 0.630 & 0.690 & 0.600 & 0.881 \\
\hline WEB1 & 0.455 & 0.040 & -0.060 & 0.027 & 0.154 & 0.539 & 0.435 & 0.623 & 0.405 & 0.796 & 0.466 \\
\hline WEB2 & 0.579 & -0.002 & 0.005 & 0.013 & 0.068 & 0.510 & 0.563 & 0.647 & 0.487 & 0.876 & 0.540 \\
\hline WEB3 & 0.543 & 0.006 & 0.071 & 0.063 & 0.073 & 0.509 & 0.497 & 0.661 & 0.425 & 0.813 & 0.456 \\
\hline WEB5 & 0.438 & 0.019 & -0.007 & 0.016 & 0.142 & 0.503 & 0.463 & 0.504 & 0.535 & 0.748 & 0.549 \\
\hline
\end{tabular}


Figures

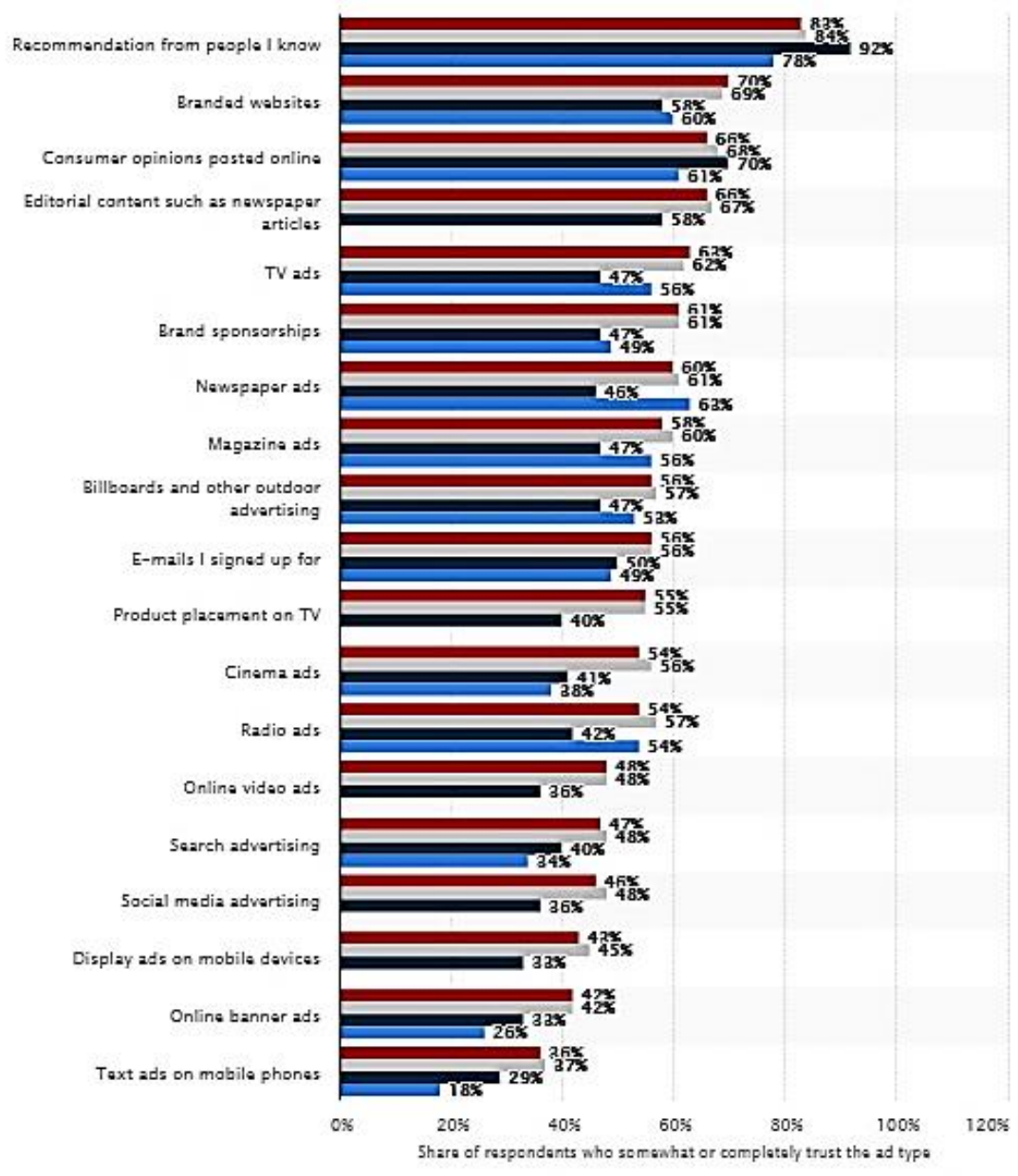

- 2007 - 2011 ○ 2013

Fig. 1. Consumer trust in advertising worldwide from 2007 to 2015 by ad format Source: https://www.statista.com/statistics/222698/consumer-trust-in-different-types-of-advertising/ 


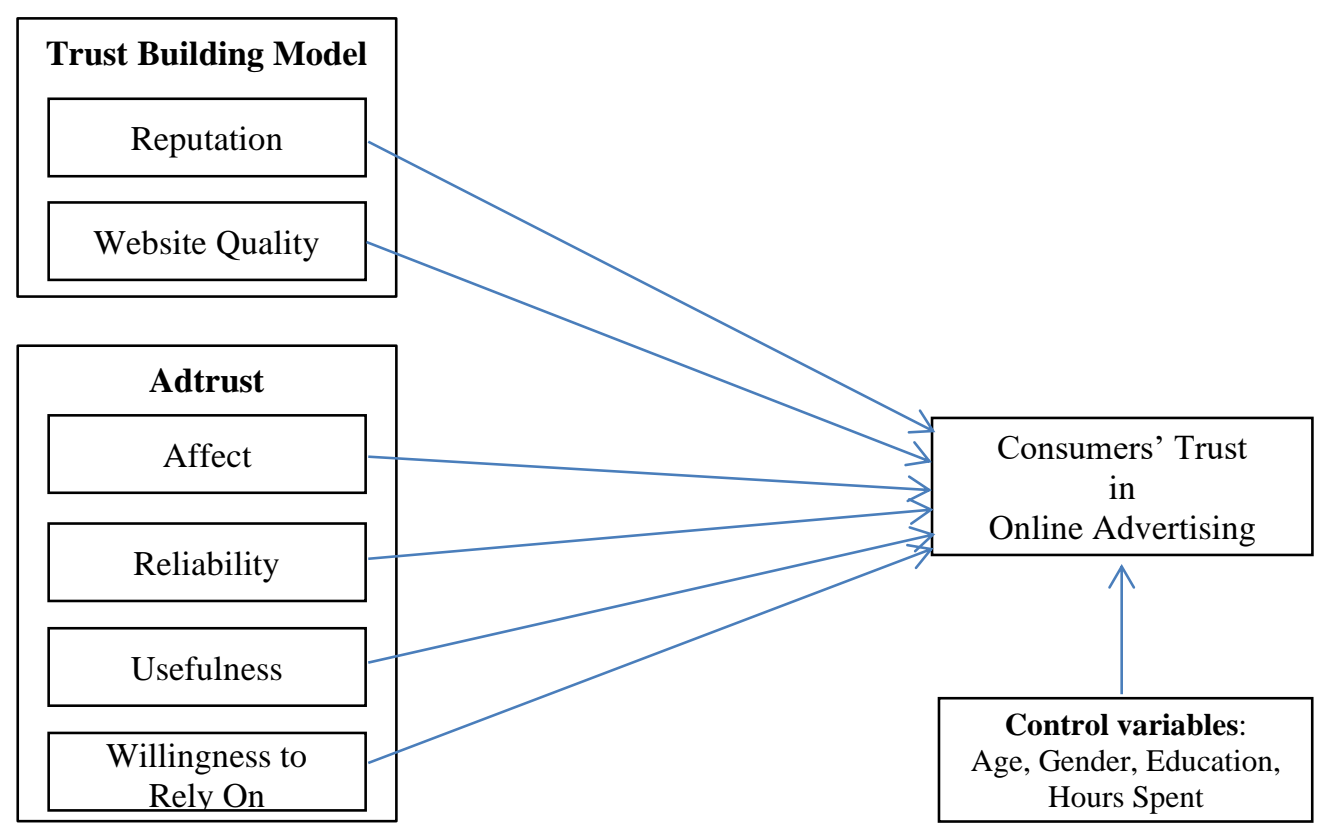

Fig. 2. Research model

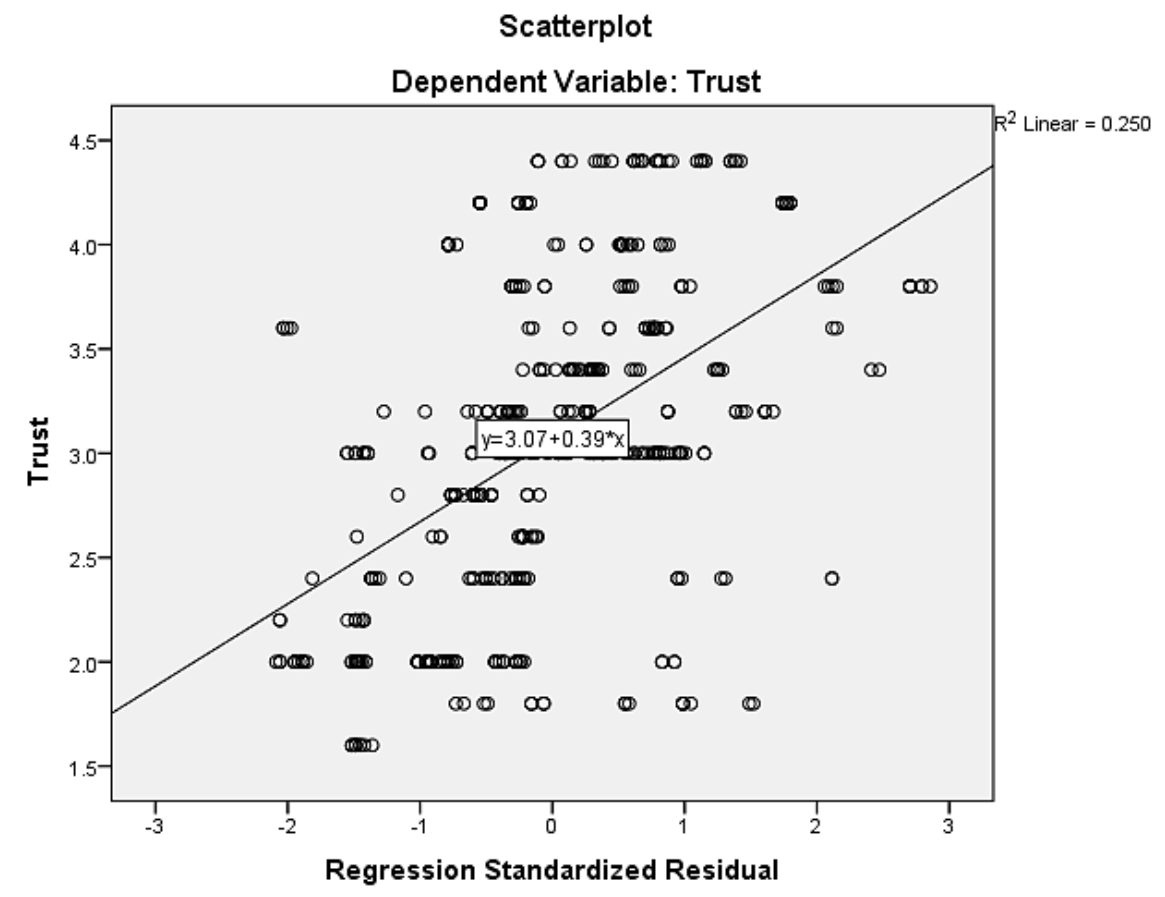

Fig. 3. Test for homoscedasticity 


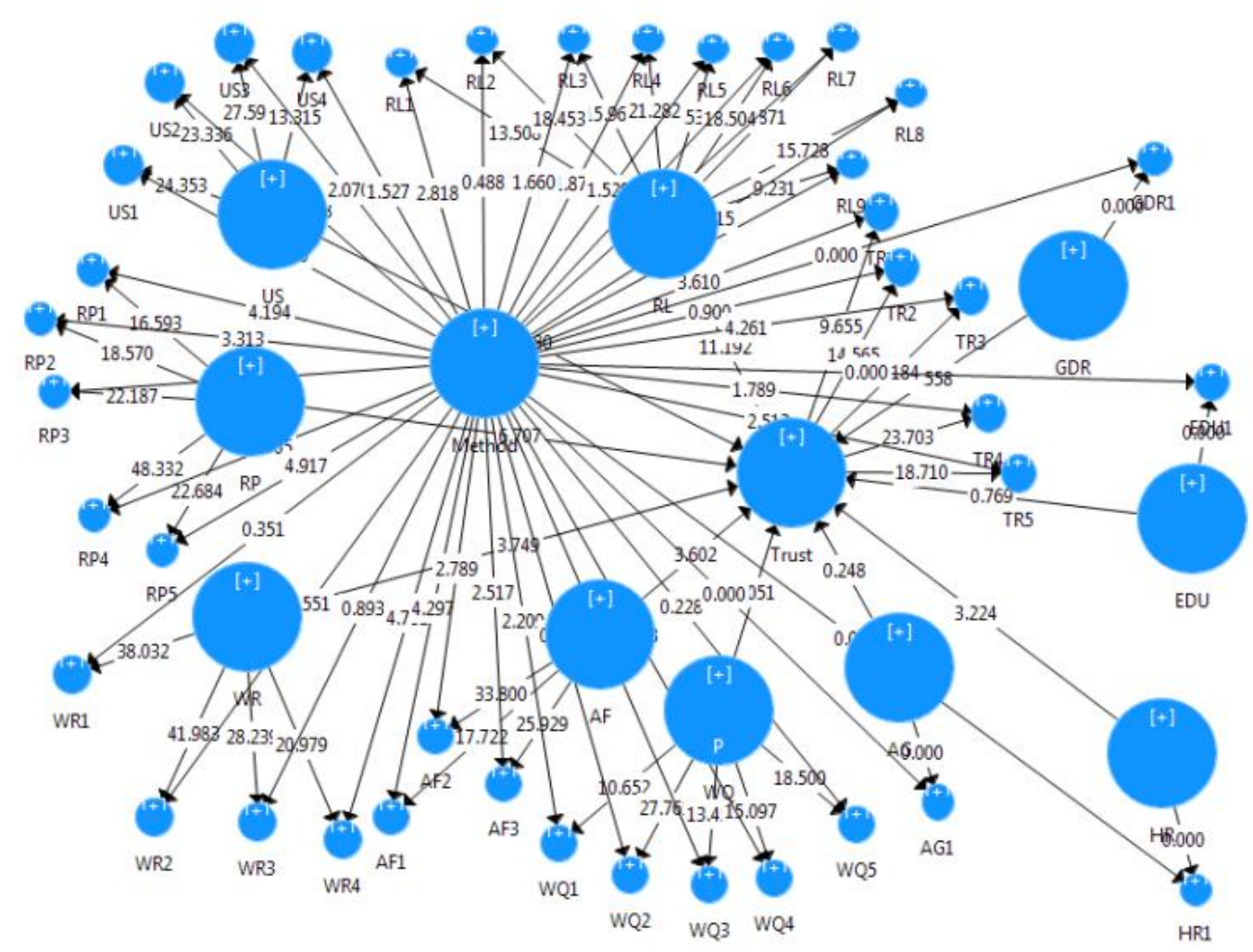

Fig. 4. Common method factor analysis

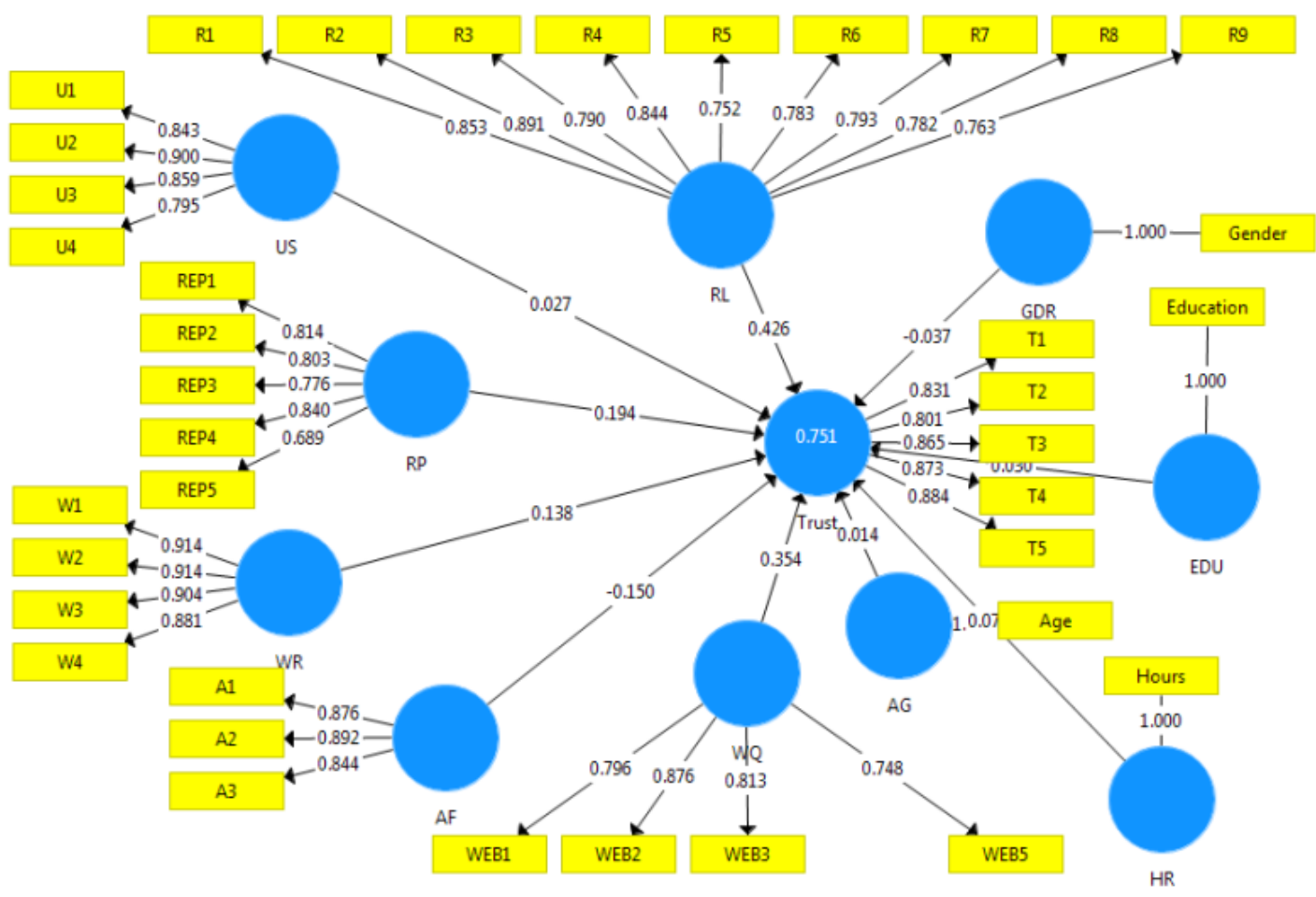

Fig. 5. Measurement model 


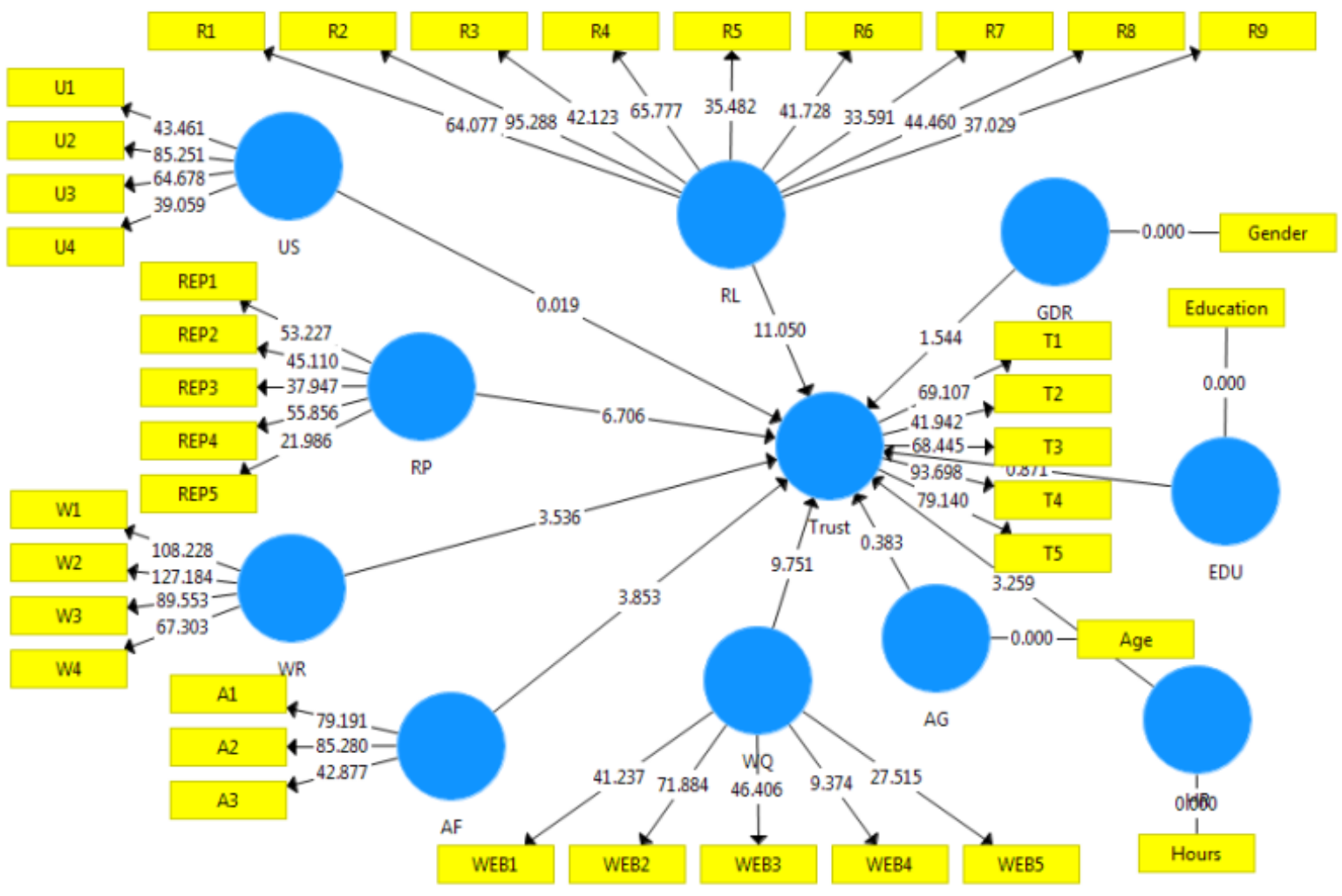

Fig. 6. Structural model 


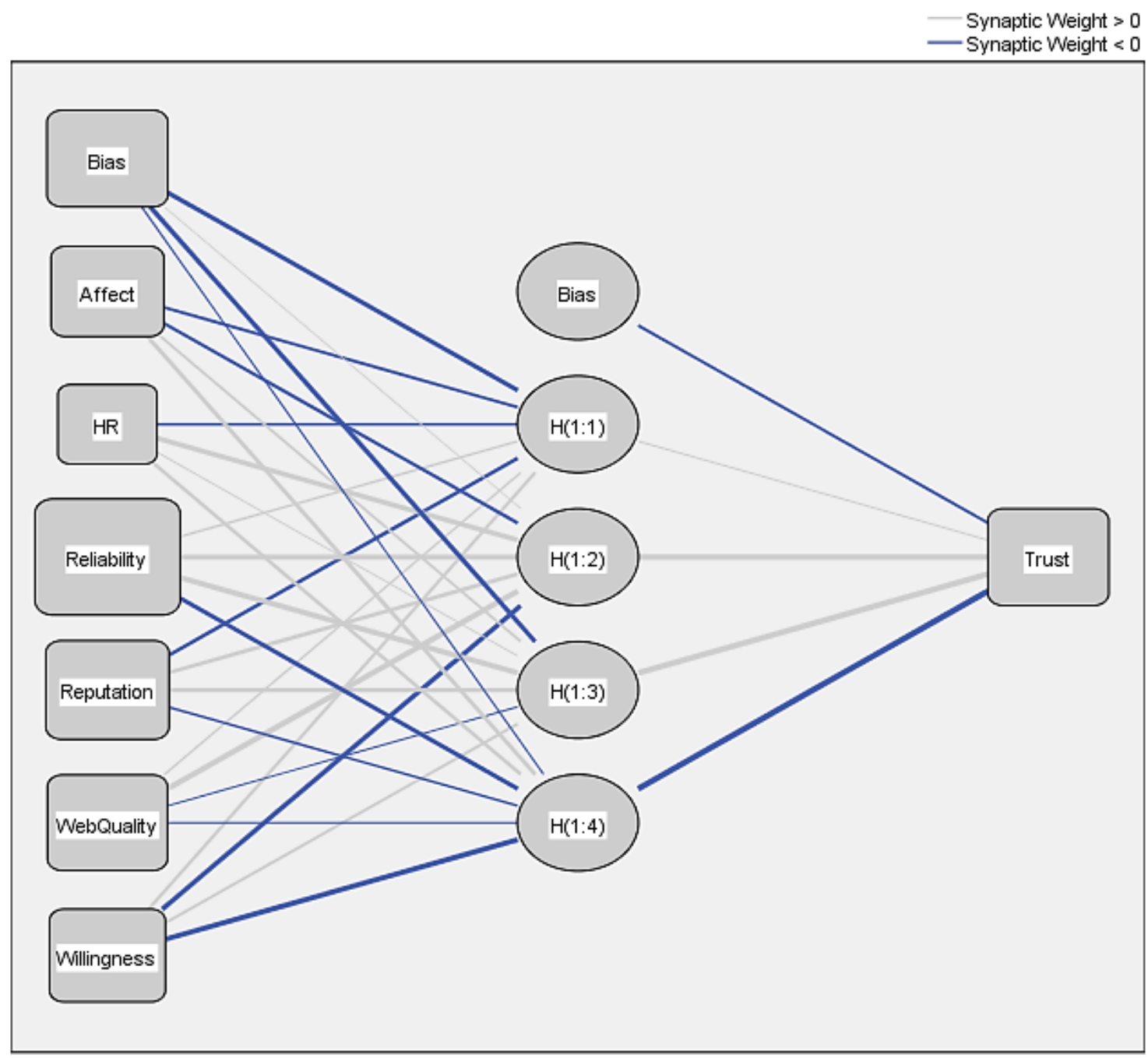

Hidden layer activation function: Sigmoid

Output layer activation function: Sigmoid

Fig. 7. Nonlinear ANN model 